B. von Bodungen - A. Antia - E. Bauerfeind

O. Haupt - W. Koeve - E. Machado - I. Peeken

R. Peinert - S. Reitmeier - C. Thomsen - M. Voss

M. Wunsch - U. Zeller · B. Zeitzschel

\title{
Pelagic processes and vertical flux of particles: an overview of a long-term comparative study in the Norwegian Sea and Greenland Sea
}

Received: 12 April 1994 / Accepted: 22 August 1994

\begin{abstract}
Pelagic processes and their relation to vertical flux have been studied in the Norwegian and Greenland Seas since 1986. Results of long-term sediment trap deployments and adjoining process studies are presented, and the underlying methodological and conceptional background is discussed. Recent extension of these investigations at the Barents Sea continental slope are also presented. With similar conditions of input irradiation and nutrient conditions, the Norwegian and Greenland Seas exhibit comparable mean annual rates of new and total production. Major differences can be found between these regions, however, in the hydrographic conditions constraining primary production and in the composition and seasonal development of the plankton. This is reflected in differences in the temporal patterns of vertical particle flux in relation to new production in the euphotic zone, the composition of particles exported and in different processes leading to their modification in the mid-water layers.

In the Norwegian Sea heavy grazing pressure during early spring retards the accumulation of phytoplankton stocks and thus a mass sedimentation of diatoms that is often associated with spring blooms. This, in conjunction with the further seasonal development of zooplankton populations, serves to delay the annual peak in sedimentation to summer or autumn. Carbonate sedimentation in the Norwegian Sea, however, is significantly higher than in the Greenland Sea, where physical factors exert a greater control on phytoplankton development and the sedimentation of opal is of greater importance. In addition to these comparative long-term
\end{abstract}

A. Antia - E. Bauerfeind - O. Haupt · W. Koeve

E. Machado - I. Peeken - R. Peinert (四) - S. Reitmeier

C. Thomsen - M. Wunsch · U. Zeller - B. Zeitzschel

Institut für Meereskunde, Düsternbrooker Weg 20,

D-24105 Kiel, Germany

email: rpeinert@IFM.uni-kiel.d400.de

B. von Bodungen - M. Voss

Institut für Ostseeforschung, Seestrasse 15,

D-18119 Warnemünde, Germany studies a case study has been carried out at the continental slope of the Barents Sea, where an emphasis was laid on the influence of resuspension and across-slope lateral transport with an analysis of suspended and sedimented material.

Key words Pelagic processes - Vertical flux Norwegian-Greenland Sea

\section{Introduction}

The Greenland-Iceland-Norwegian Sea (GIN-Sea) is recognized as a key area in the world's oceans for understanding climatic variability on a global scale due to its prominent role in the renewal of deep water and its impact on oceanic circulation. Hence it is of vital importance to assess recent scales and rates of processes that control this region's role in the carbon cycle, different aspects of which include the 'solubility pump', 'carbonate pump' and 'biological pump'. The latter comprises a variety of pelagic and benthic processes, from the primary production of biogenic particles based on $\mathrm{CO}_{2}$ reduction by phytoplankton within the euphotic zone, subsequent particle modification within pelagic food webs, particle sinking into the oceans' interior to the eventual final carbon sequesteration in deep-sea sediments.

Pelagic aspects of the biological pump were the focus of the multi-annual study in two different oceanic regimes in the GIN-Sea (Fig. 1) which we report here. The amount of material that may be exported from the surface layers is generally constrained by the amount of total primary production in the euphotic zone, which itself is the sum of new and regenerated production. New production, based on the utilization of allochthonous (with respect to the euphotic zone) nutrient sources in oceanic waters identified by nitrate is primarily dependent on physical factors, i.e. seasonal vertical mixing, upwelling and turbulent diffusion, and to a lesser extent on autotrophic nitrogen fixation and atmospher- 
Fig. 1 Positions of moored sediment traps in the Norwegian Sea (VP = Vøring Plateau; NB = Norwegian Basin). Greenland Sea (OG) and at the Barents Sea continental slope (BI)

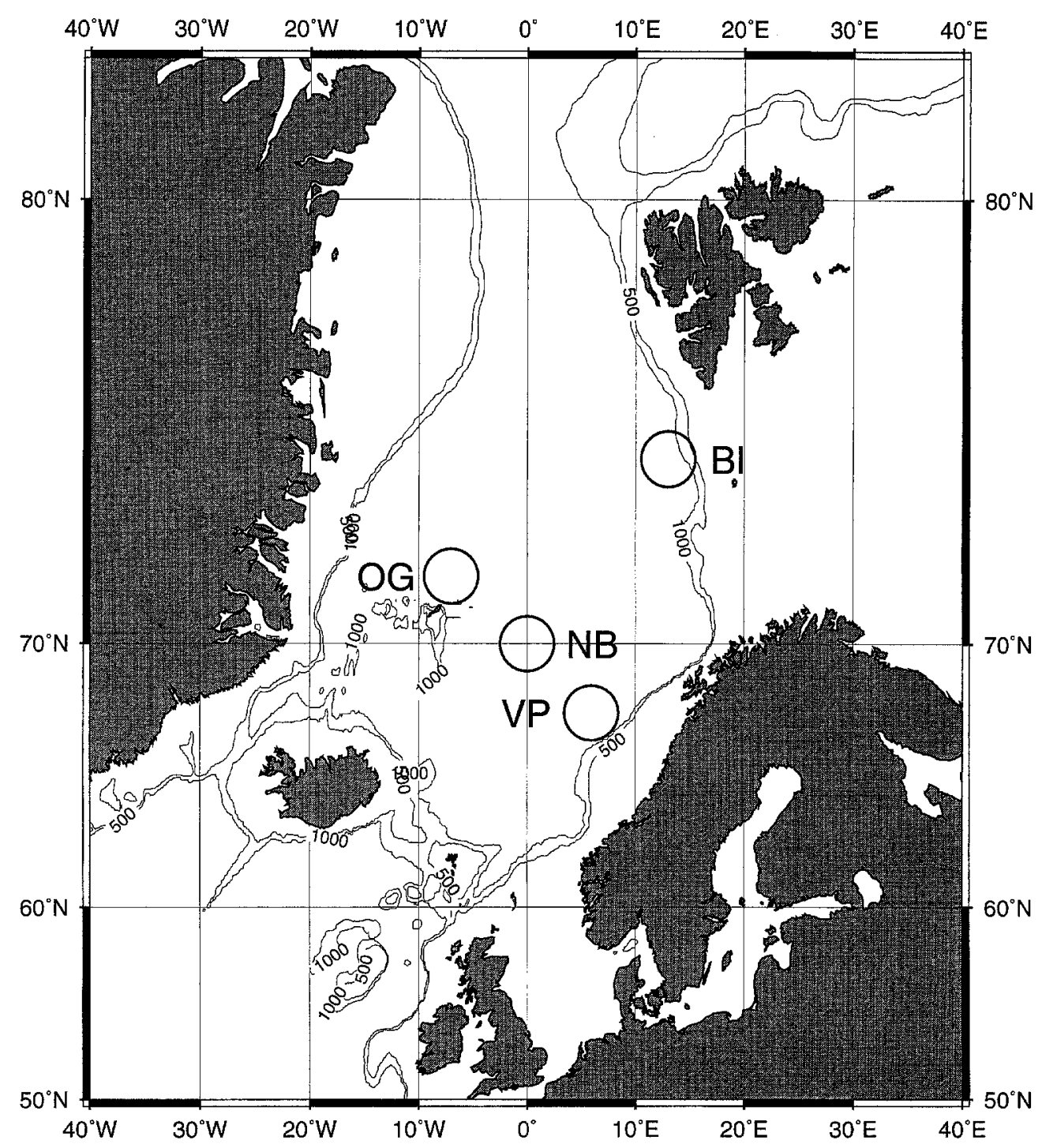

layer (often refered to as export production) on a yearly basis. The composition and seasonality in the export of particles, however, is primarily subjected to biological control (Legendre and LeFevre 1989). These processes, comprising the ocean's biological pump can significantly influence the exchange of $\mathrm{CO}_{2}$ between the ocean and the atmosphere (Berger and Wefer 1990) and can be expected to reflect alterations of oceanic circulation caused by climatic changes. Our initial hypotheses focused on pelagic system dynamics in relation to abiotic environmental conditions, and it was postulated that the physical conditions in the Norwegian and Greenland Seas result in differences in pelagic system seasonality related to different patterns of new and regenerated production, which in turn result in distinct differences in pelagic particle exports. These expectations were based on results from numerous studies in coastal, shelf and oceanic waters (e.g. Billet et al. 1983; Walsh 1983; Smetacek 1984), and our two investigation areas in the western and eastern part of the GIN-Sea were well suited to test these hypotheses. They receive similar incident irradiation and have almost the same input of new nutrients and thus new production should therefore be equal to the export from the euphotic
On an annual basis, the loss of nutrients through export of organic material is replenished by the physical transport of deeper water into the euphotic zone. The 
nutrient concentrations at the start of the annual growth period, while strongly differing in conditions of ice cover and the seasonal development of mixed-layer depth and plankton communities.

The basic concept of new and regenerated production regimes and their relationship to export still holds valid. It soon became clear, however, that a plethora of intermediate pelagic regimes may be found and our findings have added a new scenario for the Norwegian Sea. Zooplankton (primarily calanoid copepods) could be shown here to exert a controlling influence on phytoplankton growth by the beginning of spring (Bathmann et al. 1990a). Heavy grazing pressure, in fact, prevents the accumulation of phytoplankton stocks and the depletion of nutrients is delayed until well into summer. No spring vertical flux peak of phytodetritus rich in particulate biogenic silica is observed, and the annual maximum in sedimentation takes place during the late summer months (Bathmann et al. 1990b).

Zooplankters other than copepods are known to have a different impact on vertical fluxes. Swarm-building macrozooplankton such as krill and salps play a special part by their production of rapidly sinking fecal material, and episodic flux events mediated by these organisms may overlie seasonal sedimentation patterns (Bodungen 1986; Bathmann 1988). For Antarctic waters Bodungen et al. (1987) and Wefer et al. (1988) documented large spring sedimentation events high in particulate biogenic silica content in the Bransfield Strait. A total of $90 \%$ of the annual sedimentation here reached the sea bed during a single month, mainly in the form of rapidly sinking krill fecal strings. Such 'export-type systems', mediated by heterotrophs as in the above example or controlled by autotrophs when phytodetrital aggregates are exported from diatom blooms (Smetacek et al. 1990), are in contrast with 'retentiontype systems' such as encountered in the Norwegian Sea during spring or generally observed under summer regenerative conditions (Bathmann et al. 1987; Bodungen et al. 1987; Peinert et al. 1989). Both types of system may overlap or co-exist, and the export and regeneration of organic material may take place concommittantly at various trophic levels. Vertical fluxes may consequently be difficult or impossible to correlate directly to new and regenerated production on a seasonal time-scale (Legendre and Gosselin 1989).

The modification of primary formed particles takes place predominantly in the upper $300 \mathrm{~m}$ of the water column. Bacterial activity on aggregates (Smith et al. 1992), the aggregation and disaggregation of particles by zooplankton during their diel migration (Lampitt et al. 1993), and zooplankton-mediated modification of their faeces (Noji 1991) play an important part in this context. During particle formation and modification, portions that are difficult to quantify are released into the pool of dissolved organic matter (Hassan 1991; Humborg 1991). Bacterial degradation of dissolved organic matter and oxidation to $\mathrm{CO}_{2}$ (Kirchman et al. 1991) may be largely decoupled from its production in space and time, which further complicates the relationship between new production and particle export.

Significant interannual variations in the amount and composition of sedimenting particles are documented by various multi-annual sediment trap deployments (e.g. Deuser 1987). They strongly suggest that the initial conditions for spring phytoplankton growth and the coupling between autotrophic and heterotrophic processes, as well as the temporal succession of new, regenerated and export production exhibit significant fluctuations. As our understanding of fluctuations on these longer time-scales is extremely limited at present, the basis for establishing quantitative relationships between new, regenerated and export production is weak. Attempts at modelling pelagic processes indicate particular uncertainties with respect to the implications of dissolved organic matter production and the transformation of heterotrophic activity in the micro- and mesoplankton size classes on vertical particle fluxes (Fasham et al. 1993).

In the GIN-Sea, regional differences of vertical fluxes can only be understood if the effects of lateral advection and ice-edge related processes are considered. The lateral transport of particles from the continental slopes has a considerable impact on vertical fluxes even in the central basins, as shown by our results from sediment trap deployments at great depths. In the western Greenland Sea, the highly productive marginal ice zone is a prominent and permanent feature with a broad south-north extension which exhibits particular pelagic system dynamics and vertical flux patterns contrasting with those encountered in open Greenland Sea waters.

\section{Materials and methods}

The basic part of our programme consists of vertical particle flux measurements by means of long-term deployed moored sediment traps at different water depths in the western and eastern basins of the GIN-Sea. Samples were collected using KIEL automatic multisample sediment traps (AQUATEC GmbH) with a conical collection jar $\left(0.5 \mathrm{~m}^{2}\right.$ opening fitted with a baffle) programmed for a temporal resolution of between one and six weeks. Routine analyses of collected material consisted of determinations of dry weight (DW), particulate organic carbon (POC) and nitrogen (PON), particulate biogenic silica (PSi), carbonate and microscopic analyses of trap samples. Methodological aspects of trap sample handling, the preservatives used and the analytical procedures are given by Bodungen et al. (1991b). Figures 1 and 2 provide details on the locations and durations of moorings and expeditions since 1986.

Water column process studies were carried out at the mooring sites to determine the influence of pelagic processes on sedimentation patterns. Hydrographical measurements were coupled with determinations of nu- 


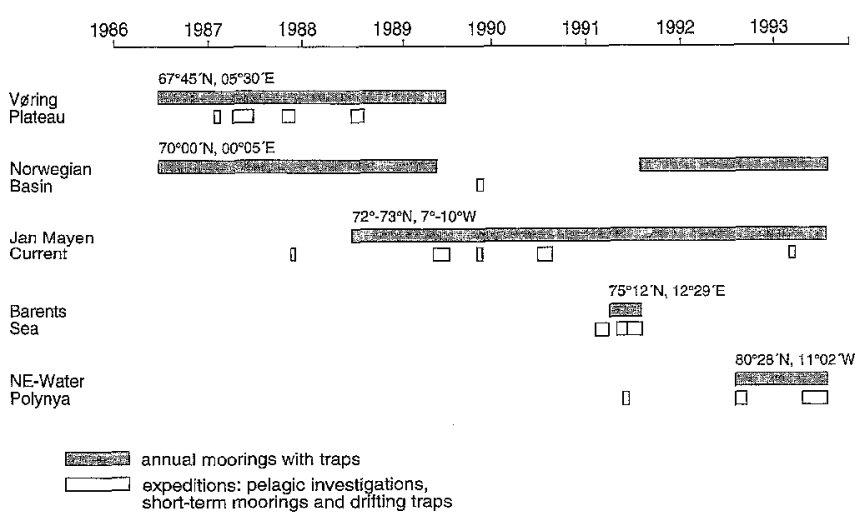

Fig. 2 Locations and durations of moorings and expeditions since 1986

trients, the bulk parameters mentioned above and algal pigments using fluorimetry and high-performance liquid chromatography (HPLC). Standing stocks of phyto- and zooplankton were determined and rate measurements of total and new primary production $\left({ }^{14} \mathrm{C}\right.$ method, ${ }^{15} \mathrm{~N}$ tracer method and chemoluminescence methods; in situ and simulated in situ) and of micro- and mesozooplankton grazing (serial dilution method, gut fluorescence) were conducted. During these process studies sediment traps were also used in a drifting mode and in short-term moorings to obtain particle flux data with a high temporal and vertical resolution.

Special emphasis was placed on the determination of mesozooplankton grazing. Incubation experiments on board ship were used to identify faecal matter of different zooplankton species to enable their identification in sediment trap material. In addition, the composition of faecal pellets was analysed and experiments were carried out to investigate the degradation of both faecal material and sedimenting detritus.

In recognition of the processes leading to the modification of particles in the water column and the necessity to determine the source of sedimenting material that is not microscopically recognizable, analyses of stable isotopes $\left({ }^{13} \mathrm{C},{ }^{15} \mathrm{~N}\right), n$-alkenones and HPLC of algal pigments were undertaken on subsamples of trapped material.

\section{Results and discussion}

\section{Methodological aspects}

Some methodological work was conducted in view of recognized caveats and problems in particle trapping efficiency of sediment traps and the use of poisons and fixatives in the sampling cups.

Buesseler (1991), using ${ }^{234} \mathrm{Th}:{ }^{238} \mathrm{U}$ disequilibria, for example, found that traps deployed in the upper $500 \mathrm{~m}$ of the water column can underestimate particle flux in spring, a finding that is in agreement with our results from the Greenland Sea during spring 1989. Drifting traps in 100 and $300 \mathrm{~m}$ were found to collect more material than a drifting trap at $50 \mathrm{~m}$ water depth. Different processes may contribute to explaining such a discrepancy. As a 'bypass' mechanism, zooplankton vertical migration (grazing at the surface and defecation in deeper layers) can transport material to deeper waters (Longhurst and Harrison 1988; Angel 1989), where it then enters the trapped pool. Further, increases of vertical fluxes with depth can result from a patchy distribution of particles sinking from surface layers, when redistribution by eddy diffusion and lateral advection takes place during sinking to greater depths (Siegel et al. 1990). As for our spring 1989 experiment, the encountered depth distribution of foraminifera offers at least a partial explanation as these protozoans had a maximum abundance below the shallow $50 \mathrm{~m}$ trap and they contributed significantly only to collections from 100 and $300 \mathrm{~m}$ depth.

Biased collection efficiencies can often be ascribed to the physical forces which traps are exposed to. Currents and shear in the flow fields may affect moored and drifting traps in different manners (Knauer and Asper 1989). However, comparative studies with these types of deployments during spring 1989 and autumn 1990 in the Greenland Sea showed a relatively good agreement between drifting and moored traps (Fig. 3). Another comparison was made between traps of different shape and opening area that were hung $40 \mathrm{~m}$ below a drifting ice platform in the Canadian Arctic for one year from September 1989. Under conditions of low temperature and low annual sedimentation rates (ca. $1 \mathrm{~g}$ dry weight $\mathrm{m}^{-2} \mathrm{a}^{-1}, 110 \mathrm{mg}$ POC $\mathrm{m}^{-2} \mathrm{a}^{-1}$ ), the difference between the two traps was less than $20 \%$ (Hargrave et al. 1994).

It is recognized that there is no single optimum poison or fixative for use in trap collections; the preservative used depends in a large part on the parameters that are to be measured (Lee et al. 1988). The use of a fixing agent in long-term moorings, however, is imperative to

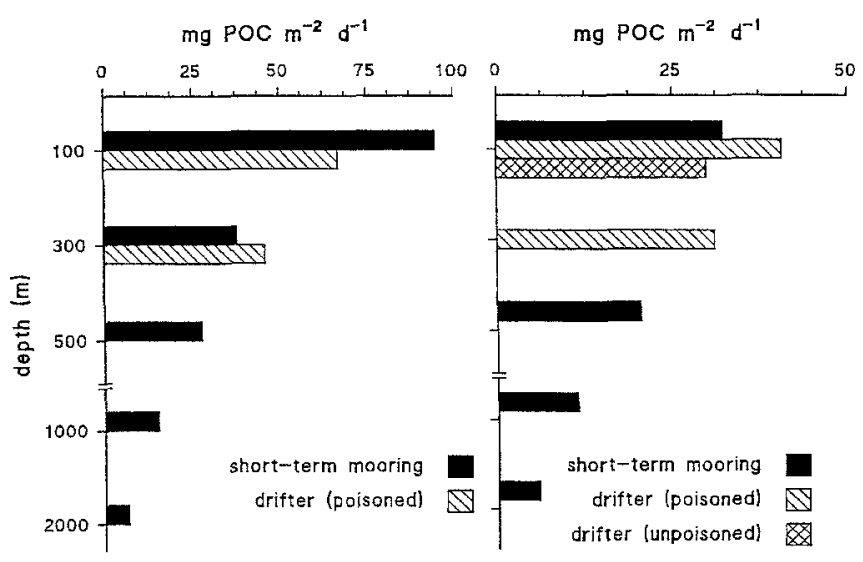

Fig. 3 Comparison of particulate organic carbon (POC) fluxes as determined by drifting and moored sediment traps for identical time intervals in the Greenland Sea. a Spring 1989; b autumn 1990. b also displays differences between poisoned and unpoisoned drifting trap samples 
prevent microbial activity and grazing within the cups by zooplankton. These so-called 'swimmers' pose a significant problem in the use of traps to measure the particle flux by introducing biases by defecation within the cups and disintegration or physical breakage of the organisms themselves. This is especially true for traps deployed above $500 \mathrm{~m}$ depth; in our deeper traps the number of zooplankton found is low. In consideration of these caveats we use mercury(II) chloride as a poison in the collector cups, which both counteracts microbial activity and kills swimmers (Lee et al. 1992) as well as not interfering with the isotopic measurements.

The results of a comparative study conducted with parallel poisoned and unpoisoned trap collections is shown in Fig. 4 where samples were recovered daily and split immediately on board ship. No significant differences were seen between the two treatments, although the number of swimmers was considerably lower in the unpoisoned collector cups, presumably as the zooplankton were able to swim out of these cups. Comparing the swimmers caught in the traps with the zooplankton composition in the water column it was evident that some zooplankton species have a higher 'affinity' for our traps (Bodungen et al. 199la; Fürderer 1991). Such experiments have been repeated by us with similar results, and in short-term deployments (less than two days) we no longer add poison or fixatives in the collector cups, but samples are poisoned immediately after recovery.

Although the addition of poison prevents biological activity it does not hinder the dissolution of PSi and carbonate from sedimented material during long-term deployments. During phases of maximum sedimentation of PSi, near-saturation concentrations can be achieved in the supernatent water of the collector cups (Fig. 5), which, however, generally comprises less than $4 \%$ of sedimenting PSi. During the winter months, when PSi sedimentation is low, however, the dissolution of up to $55 \%$ of trapped PSi in the supernatent water can occur. Routine analyses of dissolved silicate in the supernatent is thus conducted to enable corrections by addition to the particulate phase. Such a relatively simple correction is not possible for POC and
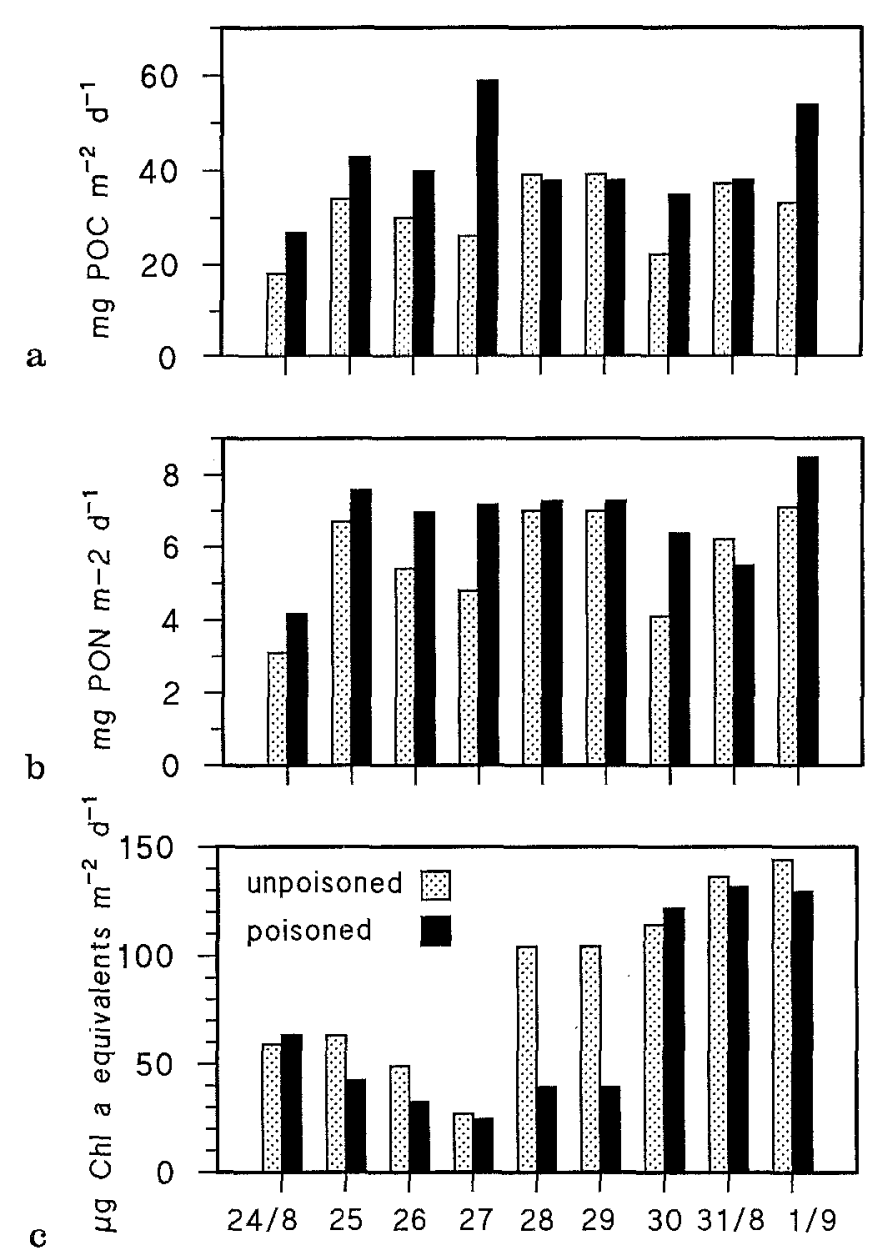

Fig. 4a-c Daily measured vertical fluxes of a particulate organic carbon (POC), b particulate nitrogen and $\mathbf{c}$ chlorophyll $a$ equivalents as determined for poisoned and unpoisoned drifting trap samples at $100 \mathrm{~m}$ depth during autumn 1990 in the Greenland Sea (from Bodungen et al. 1991b)

carbonate. To better be able to follow dissolution processes, laboratory experiments were conducted at in situ temperatures with trap material from a short-term mooring to simulate conditions of a longer deployment. During a seven month incubation losses were seen in
Fig. 5 Vertical flux of particulate biogenic silica (PSi) given as histogram (left-hand scale). Shaded parts of the histogram show portions of the PSi flux dissolved in the sampling jars (DSi). Concentrations of dissolved silicate (Si-conc) in the supernatant of trap samples from $500 \mathrm{~m}$ depth between September 1988 and June 1989 in the Greenland Sea are given as line (righ-hand scale)

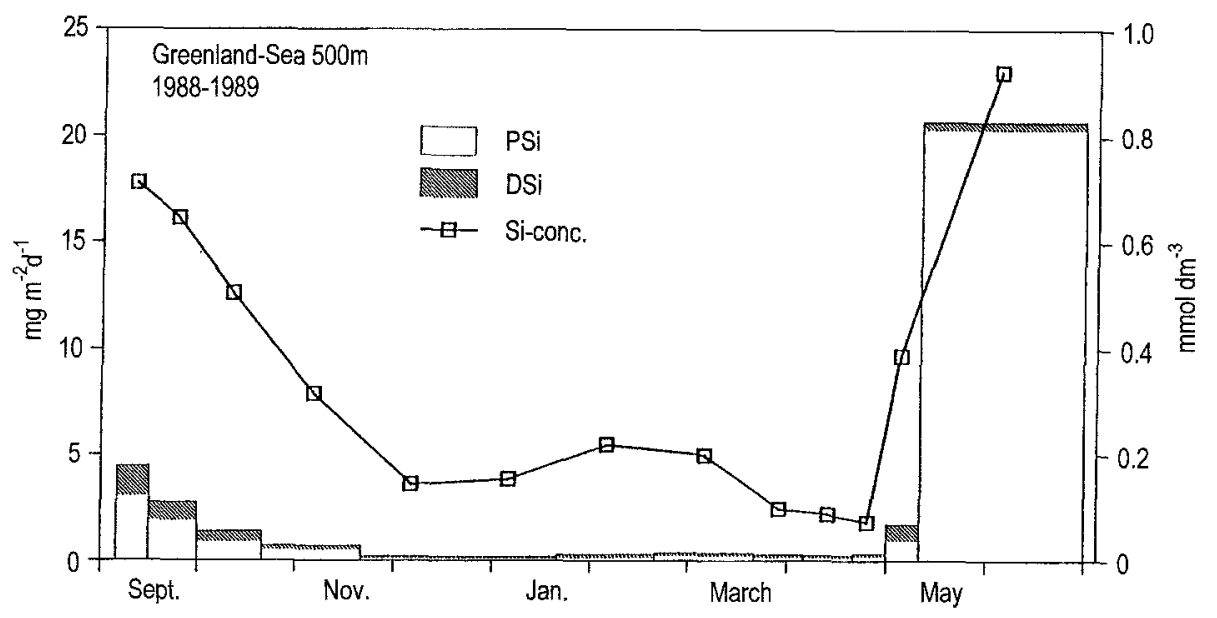


POC, PON and carbonate during the first month, after which values remained constant. Losses due to microbial degradation and carbonate dissolution in material from 100 and $300 \mathrm{~m}$ depths amounted to ca. $20 \%$; in material from 1000 and $3000 \mathrm{~m}$ depth this value decreased to about $5 \%$.

Although these experiments show some difficulties and sources of error in the estimation of vertical fluxes using sediment traps, these are within the levels of uncertainty associated with most rate measurements in marine environments. It is nonetheless possible to document seasonal patterns and interannual variability in particle fluxes, which will be discussed in the following.

\section{Norwegian Sea}

The investigations in the Norwegian Sea between 1986 and 1988 contributed significantly to differentiating the concept of a predominantly physical control on spring autotrophic growth and sedimentation. Not much attention was paid initially to the impact of the seasonal ontogenetic vertical migration of mesozooplankters on particle fluxes. Copepods ascending from overwintering depths early in the growth season in the Norwegian Sea exert a profound control on spring phytoplankton development. Heterotrophic grazing results in a slow nutrient utilization during spring and seasonal depletion in surface waters occurs as late as in July (Peinert et al. 1987; Bathmann et al. 1990b). Without significant grazing pressure, nutrients could be depleted within a period of about three weeks, as was observed in mesocosm experiments with natural phytoplankton assemblages in which zooplankton was excluded (Gloe 1988). Thus, already in early spring a complex food web with a low ratio of new to regenerated production efficiently retains biogenic elements in the pelagial. Accordingly, a spring sedimentation pulse of phytodetritus with a high diatom contribution does not take place (Peinert et al. 1989; Bathmann et al. 1990a).

Copepod faecal pellets have potential sinking velocities of $>100 \mathrm{~m} /$ day and the covering peritrophic membrane significantly slows down bacterical decomposition (Wille 1988). Aside from marine snow aggregates, copepod faecal matter has been therefore generally regarded as important transport media in vertical particle fluxes (Fowler and Knauer 1986). Our investigations strongly differentiated this concept. Copepod fecal pellets never contributed significantly to trap collections during all seasons in the Norwegian and Greenland Seas, and this holds true in particular for periods of high copepod abundance (Bathmann et al. 1987). Laboratory experiments revealed that zooplankters themselves contribute to the retention of matter incorporated in their faeces in near-surface layers. Coprophagy (=reingestion of faecal pellets), coprorhexy (=mechanical destruction) and coprochaly (=increase of volume) play important parts here (Lampitt et al. 1990;
Noji 1991; Noji et al. 1991; Voss 1991a). These laboratory-based findings were confirmed in the field by Bathmann et al. (1990a), who showed that the efficiency of this retention decreases when copepods start their seasonal vertical migration to hibernation depths. Investigations in the Nordic Seas by Gonzales and Smetacek (1994) corroborate our findings. According to these workers the ubiquituous species Oithona is specialized, apparently on feeding on faecal pellets.

Later in summer and during autumn, pteropods play an important part in the pelagic control of vertical fluxes. Their large mucoid food webs, which are often discarded, are sources for rapidly sinking aggregates. The observed seasonal maximum of carbonate fluxes in the Norwegian Sea during August/September is related to the mortality and sedimentation of these pelagic molluscs (Bathmann et al. 1991). Organism control in the Norwegian Sea also results in seasonal maxima of mass, POC and PON fluxes between June and August. The vertical flux of PSi, in contrast, is minor and exhibits a relatively weak seasonality.

The influences by copepod migration and pteropod activity, however, differ between years and vertical particle exports from the upper $500 \mathrm{~m}$ water column show a strong interannual variability (Table 1), including modifications of the overall seasonal pattern. In addition to the late summer maximum, spring peaks may also be observed. In this instance POC and PON fluxes are accompanied by a clear PSi signal due to diatom sinking. It seems reasonable to assume that in years of

Table 1 Annual fluxes of mass (dry weight; DW), calcium carbonate $\left(\mathrm{CaCO}_{3}\right)$, particulate biogenic silica (PSi), particulate organic carbon (POC) and nitrogen (PON) from 1986-1989 at three depths in the Norwegian Sea. Fluxes measured with sediment traps are given in a. To calculate advected/resuspended amounts fluxes measured at $1000 \mathrm{~m}$ were subtracted from those at $3000 \mathrm{~m}$ depth (b). Assuming that fluxes decrease with depth, this represents a minimum estimate. Footnote gives measured $\mathrm{C}: \mathrm{N}$ ratios (atoms) of organic matter for the primary flux at $1000 \mathrm{~m}$, calculated values for resuspended flux at $3000 \mathrm{~m}$ and measured ones for the sediment surface

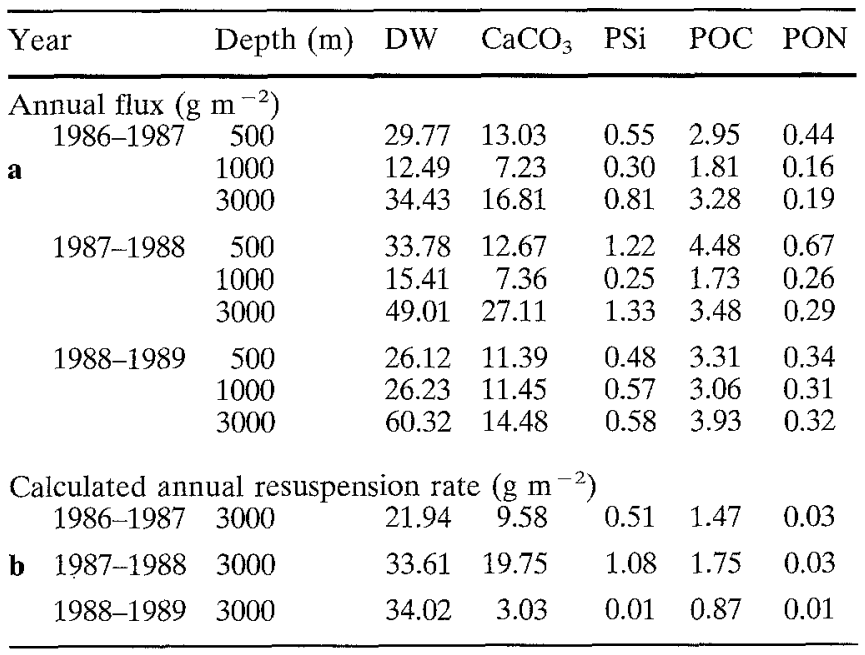

C/N ratios (atoms): primary flux, 7.9-13.2; resuspended flux, 57101; and sediment surface, 12-13. 
low zooplankton abundance during spring, a classic phytoplankton bloom may develop, parts of which would be exported via sedimentation (Bodungen et al. 1991b). However, this seems not to be so during most years and, as an interannual mean, the seasonal particle flux shows a clear seasonal maximum during late summer/autumn (Fig. 6).

Biological control of vertical fluxes in the Norwegian Sea is also underscored by stable isotope analyses of sedimented and suspended matter (Voss 1991b). During the period of maximum sedimentation, particles that are ${ }^{15} \mathrm{~N}$-depleted (relative to the $\delta^{15} \mathrm{~N}$ value of $8 \%$ of nitrate in surface water) are found at $3000 \mathrm{~m}$ depth. Particle sinking velocities $>80 \mathrm{~m} /$ day may be concluded from this finding. Laboratory experiments showed that the ${ }^{15} \mathrm{~N}$ isotope, in contrast with current theory, was not enriched in copepod faecal pellets. According to the scenario depicted above, it follows that trap collections from this period consisted of material that was reprocessed in the euphotic zone. Further, it must have been produced and exported before nitrate depletion prevailed as it was isotopically lighter than nitrate (Voss 1991b).

Vertical fluxes of alkenones $\left(\mathrm{C}_{37: 3}, \mathrm{C}_{37: 2}\right)$, biomarkers for prymnesiophytes, measured in trap samples from 1991 and 1992 show a parallel pattern. From June to August significantly increased fluxes were recorded by the deepest trap. As Phaeocystis pouchetii was not found during our investigations, this signal must be related to coccolithophorides which were incorporated in faecal matter and/or in aggregates (Thomsen 1993).

Particle resuspension and lateral advection from the continental margins, which are investigated within the SFB 313 by subproject A 1 (Blaume 1992; Rumohr and Blaume 1994), seem to have an important impact on benthic processes and the sedimentary record in the
Norwegian Sea (Graf et al. 1994; Samtleben et al. 1994). This is supported by the fact that traps at $3000 \mathrm{~m}$ collected significantly more material than those at $1000 \mathrm{~m}$ depth (Fig. 6, Table 1). From similar findings in other regions, Walsh et al. (1988) postulated the existence of 'rebound particles', which are resuspended immediately after sedimentation and, hence, still have the same composition as primary settled matter. Monthly means (data from 1987 to 1989) of the isotope composition and the magnitude of vertical fluxes al $3000 \mathrm{~m}$ depth indicate such a process for June to August in the Norwegian Sea (Fig. 6). On the basis of annual means, however, resupended particles have a significantly different composition compared with primary settling particles and sediment surface particles (Table 1). Direct resuspension of particles into the trap located $300 \mathrm{~m}$ above the seafloor may not be the major mechanism as near-bottom currents of commonly $<15 \mathrm{~cm} / \mathrm{s}$ would resuspend settled matter probably not more than $30 \mathrm{~m}$ above the seafloor (Gardner 1989). Lateral advection of particles by turbidity layers detaching from adjacent continental slopes and oceanic ridges, as shown by Blaume (1992) offers a highly probable explaination for this finding (Bodungen et al. 1991a). On an annual average these advected particles are highly degraded, as seen by their high $\mathrm{C} / \mathrm{N}$ ratios (Table 1 ).

\section{Greenland Sea}

Within the Jan Mayen Current in the southern part of the anticyclonic Greenland Sea Gyre, the seasonality of physical and biological variables and vertical particle fluxes were assessed and intensive pelagic process studies were conducted in late spring 1989 and autumn 1990
Fig. 6 Monthly means of vertical fluxes of particulate organic nitrogen (PON) and ${ }^{15} \mathrm{~N}$ contents of trap collections in the Norwegian Sea (19871989 ) at 500,1000 and $3000 \mathrm{~m}$ depth. The deepest trap was suspended $300 \mathrm{~m}$ above the seafloor

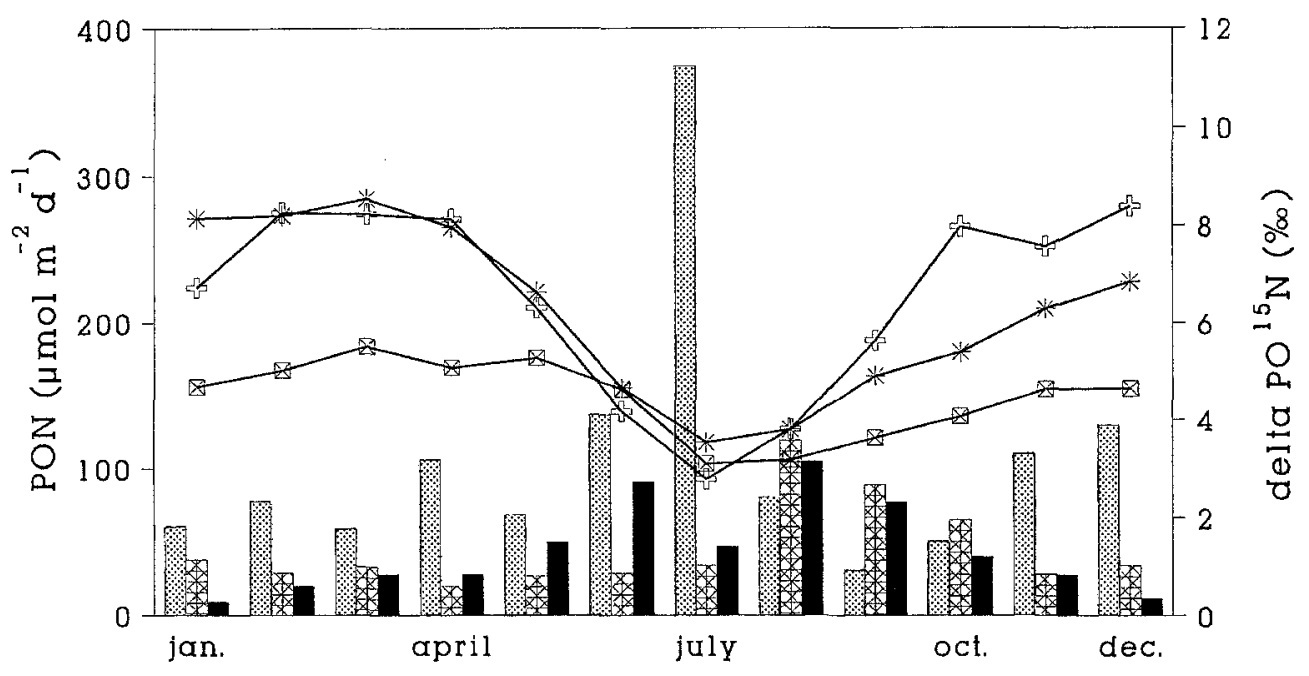

\begin{tabular}{|c|c|c|c|}
\hline & $500 \mathrm{~m}$ & $1000 \mathrm{~m}$ & $3000 \mathrm{~m}$ \\
\hline PON & ? & 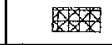 & \\
\hline delta $P O^{15} \mathrm{~N}$ & -2 & $\rightarrow$ & 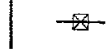 \\
\hline
\end{tabular}


in the vicinity of drifting traps and the annual sediment trap mooring site. The investigated region between 72 $73^{\circ} \mathrm{N}$ and $7-12^{\circ} \mathrm{W}$ is covered by ice during winter. Although it may be ice-free as early as February, intense pack ice coverage may prevail for variable periods thereafter, as shown by satellite remote sensing (Ramseier pers. comm.). The investigated site is typical of a large part of the western Greenland Sea as it is characterized by a highly variable ice cover rather than by a pronounced seasonal retreat as, for example, in the Barents Sea. On a long-term average, the difference between maximum and minimum ice-covered areas during winter and summer in the Greenland Sea is only 20-30\% (Smith 1987).

The highest seasonal vertical fluxes of total matter, POC and PON were measured as a broad maximum extending from May to October in 1989 and 1990 (Figs 7 and 8). PSi and carbonate fluxes followed the same temporal pattern (Machado 1993). The annual increase in particle flux in June/July at this site coincides with the melting of sea ice and haline stratification triggering spring phytoplankton growth. Trap samples from this period are characterized by high diatom contents (Machado 1993; Bauerfeind et al. in press). The shallowest trap was deployed at $500 \mathrm{~m}$ depth at this station and export from the euphotic zone in the form of diatoms may indeed be much higher, as approximately $50 \%$ of the PSi in the frustules is dissolved during their decent to $500 \mathrm{~m}$ depth (Puch 1990; Bodungen et al. 1991a; Machado 1993). Diatoms are again important contributors to trap collections during the end of the growth period in early autumn. Diatom flux seasonality and the taxonomic composition of trap samples are discussed by Samtleben et al. (1994) in relation to observations in the surface sediments.

Vertical flux events of diatoms and radiolarians were recorded in May 1989 by annually moored traps. Instruments attached to a short-term (10 days) mooring in the same region during June/July (Fig. 3a) collected

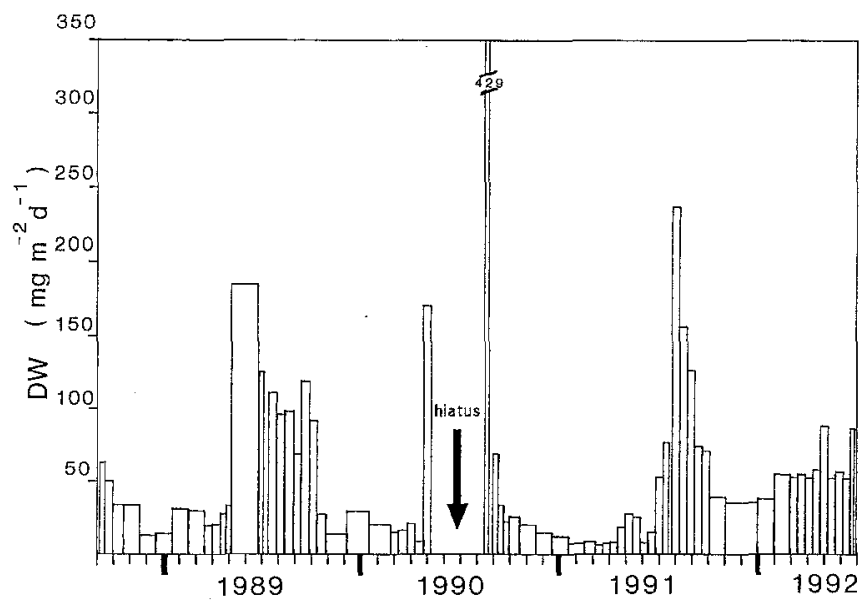

Fig. 7 Seasonality of the mass flux at $500 \mathrm{~m}$ depth in the Greenland Sea from September 1988 until September 1992. The arrow indicates a hiatus due to clogging of the trap collection jar
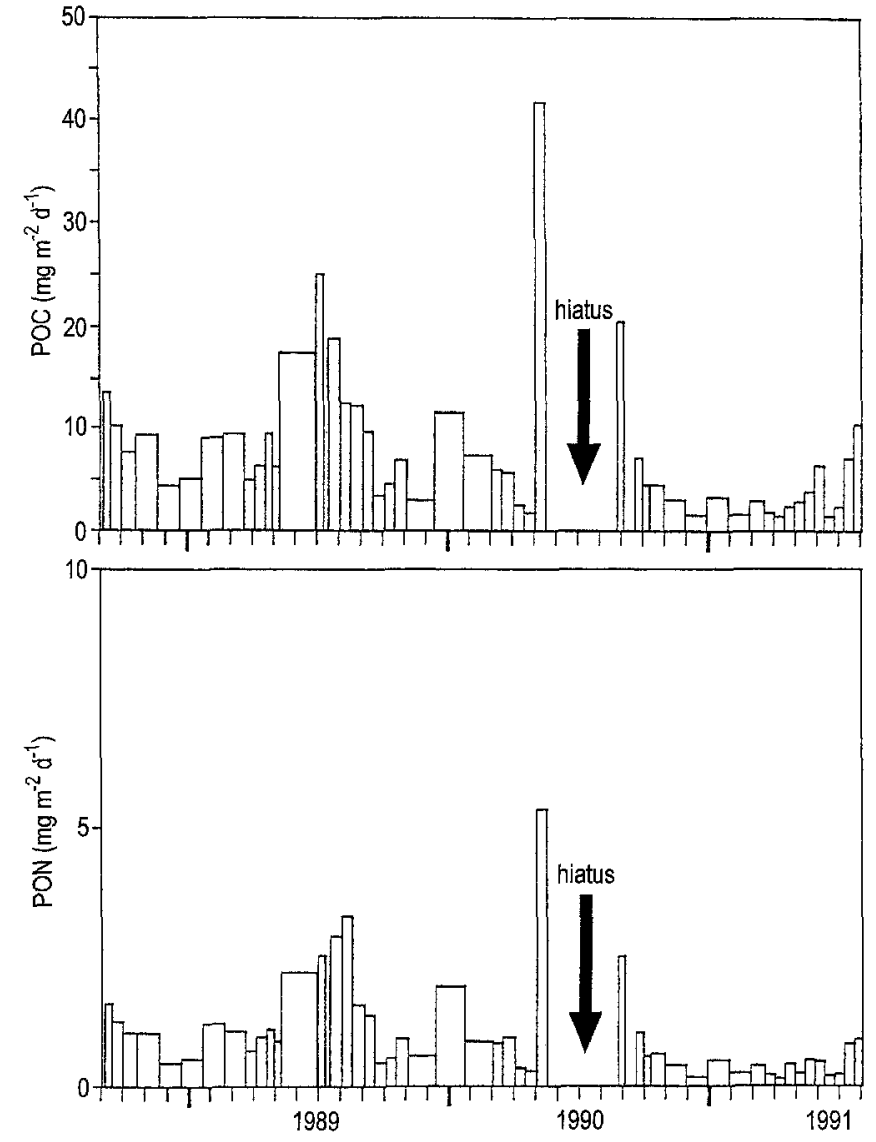

Fig. 8 Seasonal vertical fluxes of particulate organic carbon (POC) and nitrogen (PON) at $500 \mathrm{~m}$ depth in the Greenland Sea between September 1988 and July 1991. The arrow indicates a hiatus due to clogging of the trap collection jar

foraminifera, tintinnids and zooplankton faecal pellets as dominant types of sinking particles. The pigment signature of these trap collections showed a high 19-hexanoyloxyfucoxanthin content relative to fucoxanthin, indicating that much more Phaeocystis pouchetii or other prynmesiophytes, than diatoms, sedimented (incorporated in faecal pellets or as phytodetritus). A mass sedimentation of $P$. pouchetii down to $100 \mathrm{~m}$ has been documented so far only by Wassmann et al. (1990) for the Barents Sea, and the fate of the biomass produced by this flagellate is poorly known. The observed vertical decrease in particle fluxes depicted in Fig. 3a exactly follows empirical equations for the relationship between total production and particle sedimentation as formulated by Betzer et al. (1984) and Berger and Wefer (1990). The strong decrease between 100 and $500 \mathrm{~m}$ depth suggests high microbial activity and/or grazing by bathypelagic zooplankton.

Radiolarians, which are present in great numbers at the ice edge, can contribute significantly to vertical fluxes during spring and early summer. Fragile organisms of the genus Sagenoscena apparently form nuclei for large mucoid aggregates which are found in trap samples every year during early summer. The hiatus in trap data between July and September 1990 (Fig. 7), in 
fact, is due to these aggregates which clogged the lower part of the trap's collection funnel.

Foraminifera and coccolithophorids govern carbonate fluxes between May and October. Alkenone determinations on trap samples showed a significant prymnesiophyte sedimentation from July onwards. This signal, however, could not be clearly traced to greater depths and, in contrast with expectations, the ratio of $\mathrm{C}_{37: 2}$ to $\mathrm{C}_{37: 3}$ of suspended alkenones was highly variable with depth (Thomsen 1993).

Interannual variability of vertical fluxes in the Greenland Sea is as pronounced as in the Norwegian Sea (Figs 7 and 8; Table 2). In 1991 the seasonal increase of particle fluxes in May/June was small and the maximum in mass fluxes was encountered as late as October. The 1992 winter mass flux was higher than during other years and no distinct increase was observed during the following spring (Fig. 7). In summary, the annual mass flux as well as the carbonate and POC fluxes seem higher in the Norwegian Sea than the Greenland Sea, whereas the opposite is true for PSi and PON fluxes. Further, there are indications that resuspension and lateral advection to the deepest trap in the Greenland Sea is much less important.

Low fluxes encountered in 1990-1991 and the lack of a spring increase might be due to particular physical conditions prevailing during that year which, however, can only be speculated upon. In the North Atlantic Garside and Garside (1993) found a spring phytoplankton development which took place in several steps during successive phases of deep vertical mixing followed by shallow water column stratification. Such a type of spring bloom was also observed in the Baltic Sea and several vertical flux pulses were registred here (Bodungen et al. 1981). Phytoplankton accumulated during a short growth interval was transported to great depths in the course of such a mixing event (Koeve, unpublished data). As a result of alternating growth and dilution phases, particle concentrations may be kept below critical levels for aggregate formation, as was modelled for different particle concentrations by Riebesell and Wolf-Gladrow (1992). The implications for particle fluxes are evident as non-aggregation results in lower particle sinking velocities and hence promotes degrada- tion compared with export. Temporal vertical patterns and amounts exported on an annual basis would thus be highly modified. Such mechanisms would also provide an explanation for results from the North Atlantic where no spring vertical flux maximum was observed during one year and the annual flux was significantly lower than in other years (R. Lampitt, pers. comm.). In the Greenland Sea an analogous pattern could result from alternating phases of ice melting and vertical mixing. Shallow stratification seemingly promotes the growth of flagellates compared with diatoms, which, in contrast with diatoms would not sediment after a mixing event. Analyses of the vertical nutrient distributions in late spring, when $\mathrm{SiO}_{4}$, in contrast with $\mathrm{NO}_{3}$, was not yet depleted, indeed indicate that such events do take place (Koeve 1992). Whereas the relationship between new production and export production would not be affected (provided that only the euphotic zone is considered), vertical particle exports to greater depths could be highly variable as a result of these processes (Bodungen 1989).

\section{Pelagic process studies in the Greenland Sea}

Pelagic process studies including new production measurements by the ${ }^{15} \mathrm{~N}$ tracer technique were conducted for 11 and nine days, respectively, in June/July 1989 and in August/September 1990 along the trajectories of drifting sediment traps in the Greenland Sea.

In summer 1989, a close spatial co-existence of different production regimes representing different phases of seasonal plankton development was encountered in waters which had nitrate concentrations of $2-3 \mu \mathrm{mol} / \mathrm{l}$. The first phase was characterized by new production of about $2 \mathrm{mg} \mathrm{C} \mathrm{m}^{-3} \mathrm{~d}^{-1}$ with homogeneous vertical distribution in the euphotic zone and low $f$ ratios (new to total production ratio $=0.2$ ), indicating intensive nutrient regeneration (Fig. 9). The second phase had much higher $f$ ratios $(0.4-0.7)$ and new production was highest (12-46 $\mathrm{mg} \mathrm{C} \mathrm{m}^{-3} \mathrm{~d}^{-1}$ ) near the surface (Koeve 1992). Differences in new production were accompanied by a change in phytoplankton composition. The prymnesiophyte Phaeocystis pouchetii dominated when

Table 2 Hydrographic and production characteristics of the investigations sites in the Norwegian Sea and Greenland Sea

\begin{tabular}{lll}
\hline & Greenland Sea & Norwegian Sea \\
\hline Geographical position & $72-73^{\circ} \mathrm{N} ; 6-10^{\circ} \mathrm{W}$ & $70^{\circ} \mathrm{N} ; 00^{\circ} \mathrm{E}$ \\
Water depth $(\mathrm{m})$ & $>2500$ & $>3400$ \\
Characteristic & Polar water & Atlantic water \\
Water mass & $(0-150 \mathrm{~m}$ depth) & $(0-500 \mathrm{~m}$ depth) \\
Salinity (psu) & $<34.4$ & 35.1 \\
Temperature $\left({ }^{\circ} \mathrm{C}\right)$ & $<0-$ max. 5 & $3-12$ \\
Ice cover & Temporary (Dec-Apr) & Permanently ice-free \\
Winter nitrate concentration $(\mu \mathrm{mol} / \mathrm{l})$ & 12.8 & 12.6 \\
Total production $\left(\mathrm{g} \mathrm{m}^{-2} \mathrm{a}^{-1}\right)$ & ca. 85 & ca. 90 \\
New production $\left(\mathrm{g} \mathrm{m}^{-2} \mathrm{a}^{-1}\right)$ & ca. 27 & $21-29$ \\
\hline
\end{tabular}




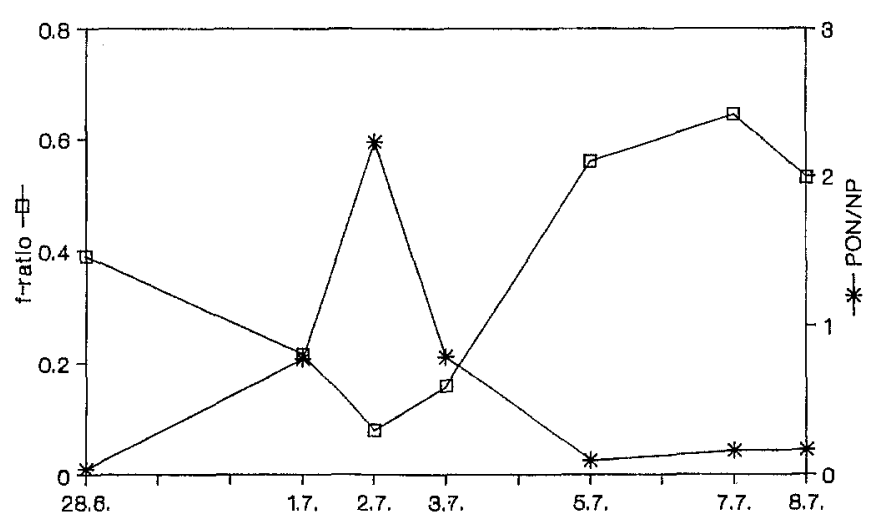

Fig. $9 f$ Ratios and ratios of PON sedimentation to new production (PON/NP) as calculated for stations in the Greenland Sea from June to July 1989 (PON = particulate organic nitrogen; new production $={ }^{15} \mathrm{NO}_{3}$ uptake)

new production was low, whereas it was absent in the other phase where diatoms prevailed (Arndt 1990). Both regimes did not differ with respect to the grazing pressure exerted by micro- and mesozooplankton (Antia 1991; Zeller 1990). Differences in new production may thus not be due to the inhibition of nitrate uptake by regenerated ammonium alone, but rather result from the combined effect of light supply and phytoplankton species composition (Koeve 1992). Such a control would differ from conditions at lower latitudes where new production is largely controlled by nitrate concentrations in the euphotic zone (Eppley and Koeve 1990; Koeve et al. 1993).

About $70-80 \%$ of nitrate but only $30-50 \%$ of silicate reservoirs had been utilized at the time of our summer investigation. A detailed analysis of vertical nutrient distributions suggests that a population of Phaeocystis pouchetii and/or other flagellates had grown before diatoms during spring. Flagellates and in particular $P$. pouchetii are often found to dominate in ice edge waters during spring (Gradinger and Baumann 1991; Smith et al. 1991). It should be noted, however, that the two phases encountered during our study do not represent a succession in phytoplankton development, but instead evidence mesoscale heterogeneities in the spatial distribution of pelagic production and heterotrophic activities typical of the transition period from spring to summer (Bodungen et al. 1990).

The vertical flux of particulate nitrogen from the upper $100 \mathrm{~m}$ was equal to $16 \%$ of new production during the investigated period. However, pronounced day to day differences were observed for the ratio of particulate $\mathbf{N}$ export to new $\mathbf{N}$ production (Fig. 9). Relative PON exports were particularly high $(>1)$ when $\mathrm{N}$ regeneration in the water column was intense (low $f$ ratio). In contrast, they were low $(<0.2)$ during days when high $f$ ratios $(>0.4)$ prevailed. For the latter conditions it may be concluded that a large portion of new production must have been channelled into the dissolved organic matter pool and/or accumulated in slowly sinking particles.
During the investigation in August/September 1990, a much more homogeneous distribution of pelagic processes was found compared with the summer study (Antia et al. 1990). New and total production of maximal 2 and $8 \mathrm{mg} \mathrm{C} \mathrm{m}^{-3} \mathrm{~d}^{-1}$, respectively, were much lower than in early summer and the $f$ ratio ranged from 0.1 to 0.2 . Daily removal of suspended chlorophyll by microzooplankton grazing was 1-17\% (Antia 1991). Despite relatively high nutrient regeneration within the euphotic zone, no significant inhibition of new production by ammonia can be deduced from field data and conducted laboratory experiments (Koeve 1992). As observed during spring 1989, the vertical distribution of new production was related to those of nitrate concentrations and light penetration. The upper $10 \mathrm{~m}$ of the water column were nitrate-depleted and light supply was largely reduced according to the season (Antia et al. 1990; Koeve 1992).

Protozoans deserve further attention here. Vegetative acantharian cells were fairly abundant in the upper $50 \mathrm{~m}$ and their cysts were found in the upper $300 \mathrm{~m}$ of the water column. Vegetative cells and cysts contributed $1 \%$ to POC in the euphotic zone. However, results from sediment trap drifters and short-term moorings (Fig. 3b) showed that acantharian cysts accounted for up to $90 \%$ of the daily vertical POC export from the upper $100 \mathrm{~m}$ and $55 \%$ was calculated as the average contribution during the nine-day experiment (Antia et al. 1993). The portion of settled POC related to acantharians, however, could not be quantitatively traced to greater depths due to the rapid dissolution of their strontium sulphate skeletons, in particular between 500 and $1000 \mathrm{~m}$ depth.

Aside from the acantharians, phytoplankton also contributed significantly to the vertical flux during this period, as evidenced by microscopy and pigment determinations of trap samples by HPLC. Fucoxanthin and peridinin evidenced the contributions by diatoms and dinoflagellates to trap samples down to $2200 \mathrm{~m}$ depth. Increasing phaeophytin and pyrophaeophytin contributions to trap samples with depth suggest the progressive senescence of algal cells while settling. Carotenoids, although thought to be relatively stable pigments, were not detected in samples from the deeper traps. Significant amounts of phaeophorbides (in particular pyrophaeophorbide) and fucoxanthiol in trap collections indicate the contribution of zooplankton faecal pellets to sinking particles (Peeken, in prep.).

During the nine days in autumn vertical export was about half of that observed during the 10 day period in early summer (Fig. 3). However, POC fluxes in autumn amounted to $180 \%$ of new production in that period compared with $16 \%$ in early summer. This clearly suggests that a significant phase shift between production and export, as shown for periods of days (Fig. 9), may also take place at a longer (seasonal) time-scale. During autumn, the vertical decrease in particle fluxes was much less pronounced than in summer (Fig. 3) and the relatively high chlorophyll contents of trap samples at 
depths up to $2200 \mathrm{~m}$ suggest a rapid export of fresh material. A lower activity of bathypelagic communities after spring would explain this significantly higher export to greater depths. Further, sinking acantharian cysts (settling velocity estimated to be about $200 \mathrm{~m} \mathrm{~d}^{-1}$ ) could have contributed to high POC fluxes, although their celestite housings rapidly dissolve.

The pronounced seasonal differences in the ratio of export to new production support the observation that, on a seasonal basis, there is no straightforward relationship between the amounts, composition and vertical decreases of particle fluxes on the one hand and new or regenerated production on the other.

\section{Barents Sea continental margin}

The Barents Sea is known to export significant amounts of resuspended material mediated by cascade-like winter outflows of dense bottom water (Blindheim 1989; Blaume 1992). Particle flux measurements in this region accordingly showed the annual maximum during winter with a clear dominance of lithogenic particles (Honjo 1990). Our investigations in winter, spring and summer show that the source and composition of settling pelagic particles are highly variable on a scale of weeks, also reflecting phytoplankton and grazer development in the waters of Atlantic origin. A combination of biomarker analyses, quantitative microscopy and bulk parameter determinations on water and trap samples revealed a complex juxtaposition of pelagic biological processes and lateral advection, which jointly controlled fluxes in this region.

Our results show that cross-slope lateral particle transport during the growth season may sweep freshly settled pelagic material from the Barents Sea into the deep Norwegian Sea, Vertical flux measurements with a high temporal resolution suggest a partitioning of the investigated period into three distinct phases. Between March and mid-May (phase I), vertical fluxes were minor (POC data given in Fig. 10). Primary vertical fluxes, i.e. particles of pelagic origin settling for the first time after production, started to increase after mid-May, and a clear maximum was registred in late June (phase II). This pattern was registered at all trap deployment depths. In July, particle fluxes as measured at $610 \mathrm{~m}$ depth decreased again, but strongly increased with depth. Although increasing mass fluxes with depth and increased ratios of lithogenic to biogenic components in the deeper trap collections suggest an input of resuspended and/or laterally advected sediment particles throughout the entire investigation period, these processes were clearly most important in quantity during phases II and III. Further, the composition of advected particles changed between phases II and III. Although freshly produced matter with a significant contribution of undegraded phytoplankton was collected during phase II, further processed material with a minor phytoplankton component dominated trap samples thereafter during phase III.
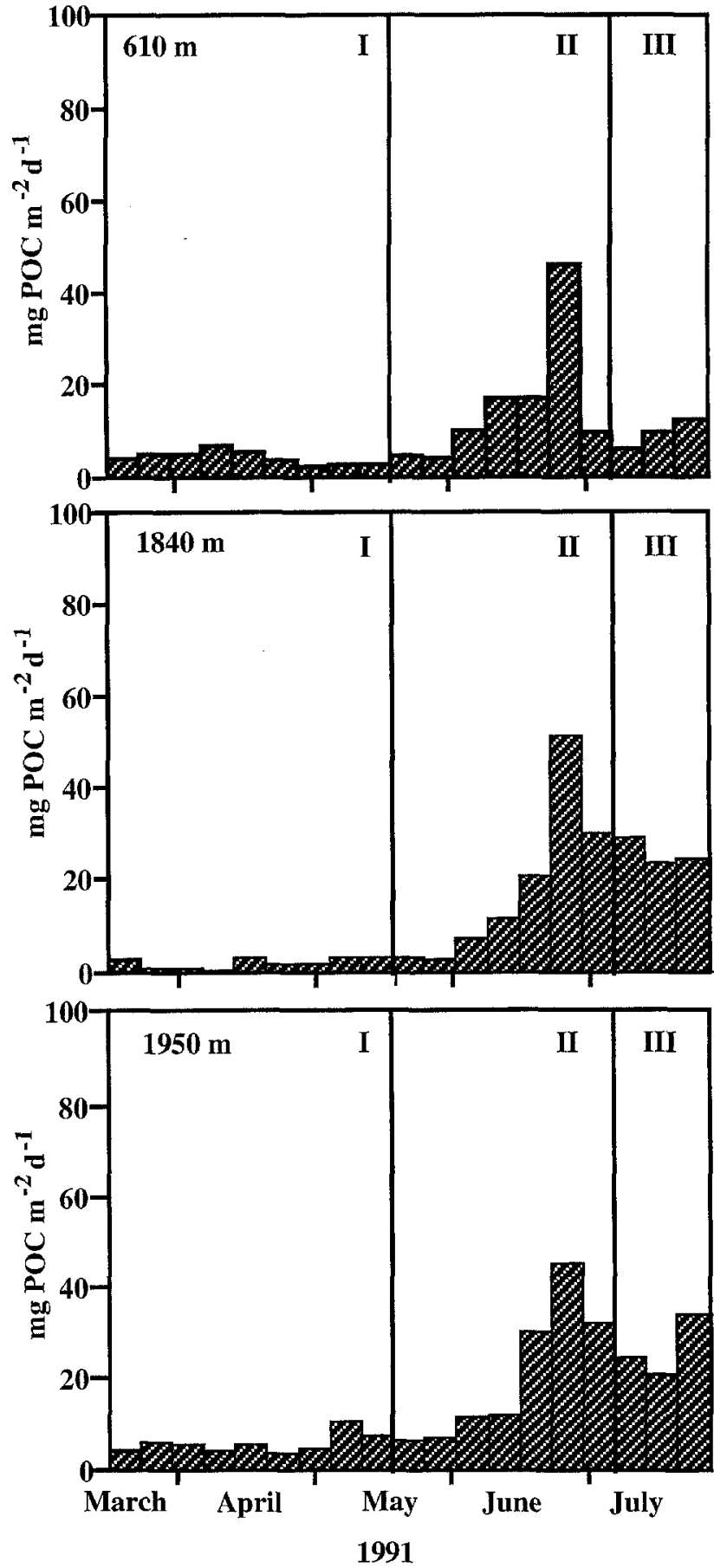

Fig. 10 Particulate organic carbon (POC) flux between March and July 1991 at 610,1840 and $1950 \mathrm{~m}$ depths at the Barents Sea continental slope (water depth $2200 \mathrm{~m}$ ). Vertical lines separate phases I-III of particle flux

Analyses of algal pigments by HPLC contributed to differentiation between sources of sinking particles (Fig. 11). Shallow trap collections from $610 \mathrm{~m}$ depth showed that the pulse of chlorines during phase II consisted of undegraded chlorophyll $a$ as well as phaeopigments (phaeophorbides and phaeophytins). The primary source of this sedimentation event was diatoms, but prymnesiophytes, dinophytes, cryptophytes and chloro- 


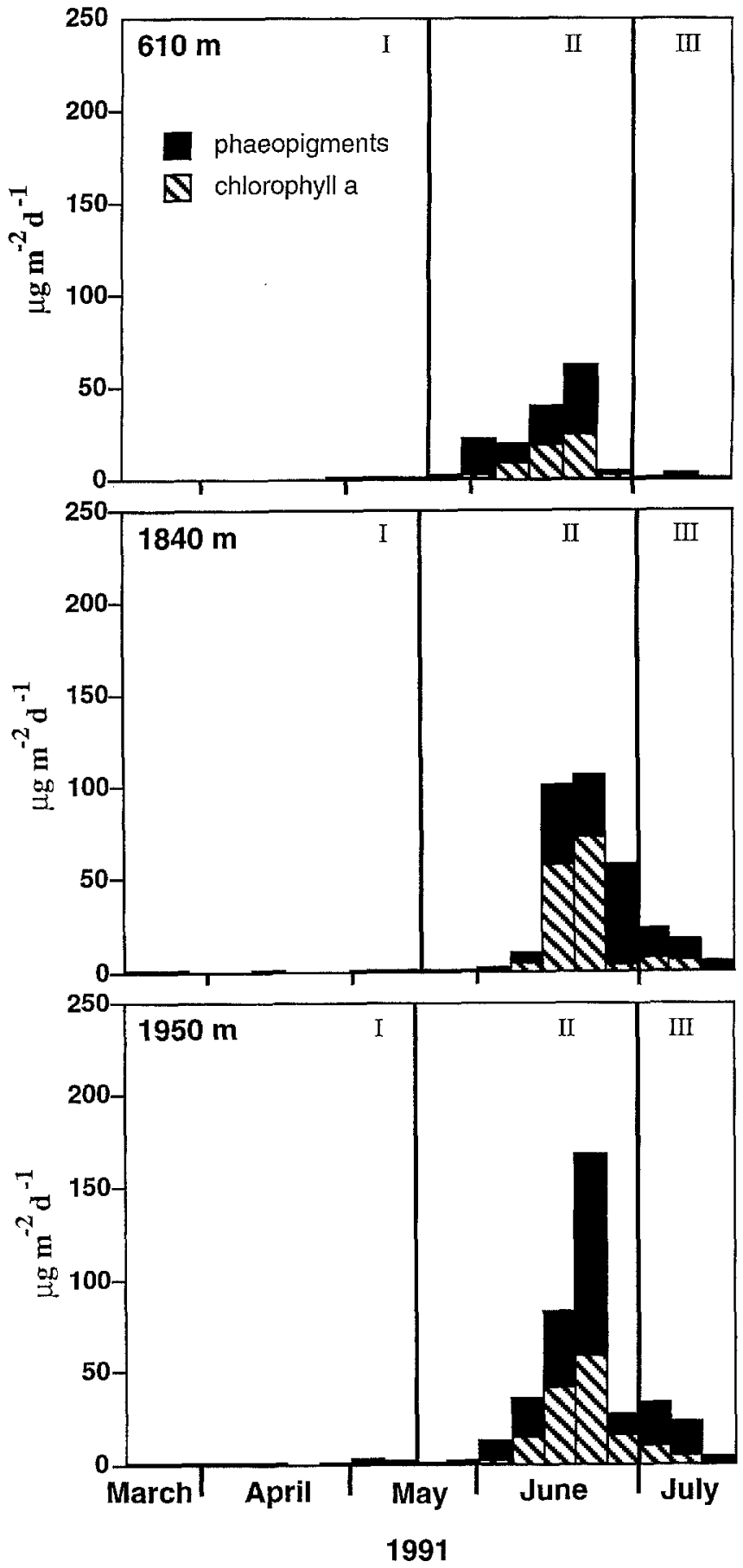

Fig. 11 Fluxes (stacked bars) of chlorophyll $a$ (shaded) and phaeopigments (solid) between March and July 1991 at 610, 1840 and $1950 \mathrm{~m}$ depths at the Barents Sea continental slope. Vertical lines separate phases I-III

phytes contributed as well, as evidenced by detailed marker pigment analyses (Peeken, in prep.) not presented here. The pigment signature of trapped particles evidences a parallel settling of zooplankton faecal pellets and of undegraded but probably senescent phytoplankton from the euphotic zone. Attention is drawn to the fact that fluxes of both fresh and degraded pigments increased with depth and that the peak was re- corded with a phase shift and was more spread out at greater depths close to the seafloor. We conclude that lateral transport from the shelf, as discussed by Blaume (1992), is mainly responsible for this phenomenon. This is supported by the presence of as yet unidentified chlorophyll degradation products in the trap samples, which were also found in surface sediments but were absent in the water column. Characterized by an absorbance spectrum similar to purpurins, which are known degradation products in marine sediments, these compounds were found in particular in surface sediments at $375 \mathrm{~m}$ water depth east of the position of our trap mooring and - in lesser amounts - also at stations down the continental slope. Analyses of other biomarkers by Thomsen (1993) are in line with this reasoning. Further to organic matter degradation products, during this time of the year fresh material is also potentially available for advection from the Barents Sea, as maximum autotrophic biomass accumulation and sedimentation have been recorded there in May/June (Wassmann et al. 1991). Our measurements do not allow us to quantitatively separate lateral from vertical imputs, and it is not ruled out that high particle fluxes during phase II may also have been related to sedimentation of a prior bloom in the region of the mooring site itself. This possibility is indicated by the fact that trap collections contained chlorophyll $a, b, c 1+2$ as well as fucoxanthin, diadinoxanthin and alloxanthin, with a similar composition to particles suspended in the euphotic zone at that site (Peeken, in prep.). In this instance particle sinking velocities of about $200 \mathrm{~m}$ day $^{-1}$ would be postulated from the phase shift of recordings at greater depths.

Seasonal zooplankton migration into high production shelf regions contributes to control the exchange of matter between the shelf seas and the ocean basins (Walsh 1989). Our study thus also paid attention to zooplankton seasonality and the fate of faecal pellets produced by a variety of species (Fig. 12). For this purpose also ship board feeding experiments were conducted to compare freshly produced pellets with those collected by sediment traps. Seasonal zooplankton migration is apparent from the fact that abundances in the upper $300 \mathrm{~m}$ layer increased from $<6$ to $>900$ individuals $\mathrm{m}^{-3}$ from winter to spring and during the same period decreased at greater depths. Zooplankton was dominated by copepodes (with a prominent fraction of Calanus finmarchicus). Copepod lipid contents strongly decreased from winter to spring and lipid stores were replenished as late as in summer before hibernation commenced. Feeding experiments showed a clear relationship between respiration and food availability (Zeller in prep.). From faecal pellet analyses of sediment trap collections it was concluded that appendicularians had also been highly abundant although, during the expeditions, they were not encountered in large numbers in the water column. Faecal pellets of ostracods and, in particular, appendicularians contributed significantly to trapped POC (Fig. 13; Zeller in prep.). In contrast with the dominant role of copepods in the 


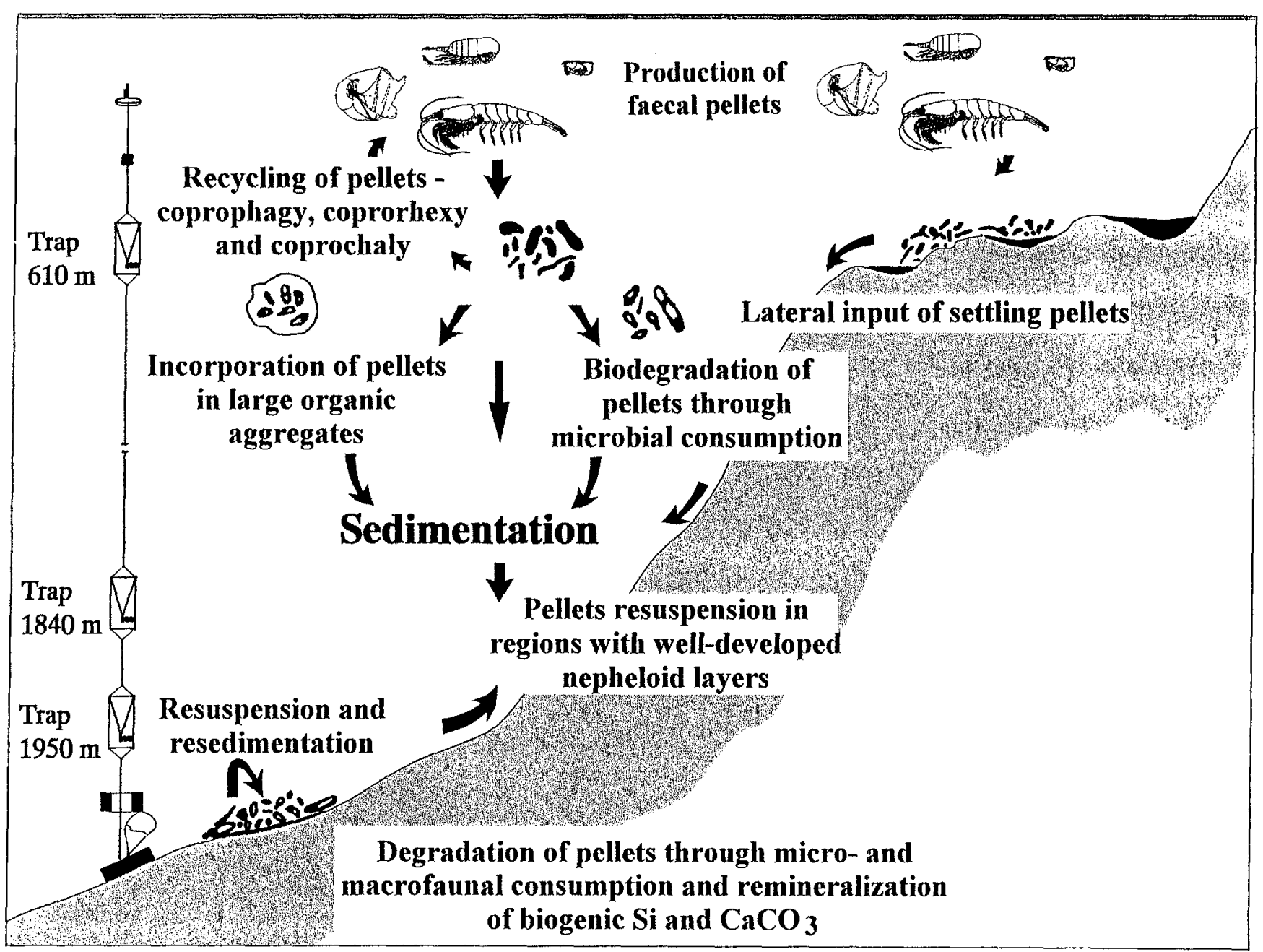

Fig. 12 Schematic relationship between processes that control the distribution and fate of mesozooplankton faecal pellets at the continental slope. Depth positioning of the sediment trap mooring about 40 nautical miles west of the $2000 \mathrm{~m}$ isobath at the entrance to the Barents Sea

zooplankton, fluxes of their pellets only played a minor part. The highest faecal pellet sedimentation was recorded parallel to pigment fluxes during phase II. However, pellet fluxes exhibited another major increase during phase III, when pigment sedimentation had stopped. Increasing pellet fluxes with depth may be due to zooplankton grazing below $610 \mathrm{~m}$. It is likely, however, that pellets were also part of an unselective downslope advective transport of particles from the continental margin.

The three phases observed for vertical fluxes of biogenic elements and pigments were also reflected in the flux of alkenones, a biomarker for prymnesiophytes (Thomsen 1993). The temporal vertical flux pattern for alkenones, however, was less pronounced than for the components discussed earlier. Trap samples from $1840 \mathrm{~m}$ depth were comprised of relatively fresh material with an alkenone $\mathrm{C}_{37: 2}$ to $\mathrm{C}_{37.3}$ ratio $<0.5: 1$. Collections from $1950 \mathrm{~m}$, only $100 \mathrm{~m}$ deeper, had signifi- cantly higher ratios of about $2-6: 1$. Such differences in the vertical distribution at great depths were also observed at other mooring sites in the Norwegian-Greenland Sea and may be taken as an indicator for the variable influence of resuspension on trap collections in near-bottom layers (Thomsen 1993). The presence of coccolithophorids (prymnesiophytes) could also be documented by electron microscopic analyses of zooplankton faecal pellet contents. In particular, Emiliania huxleyi and Coccolithus pelagicus were found in faeces of ostracods, euphausiids appendicularians and copepods (Zeller in prep.). Trap sample pigment analyses, however, did not detect the carotenoid 19' -hexanoyloxyfucoxanthin typical of prymnesiophytes (Peeken in prep.).

In summary, the role of zooplankton in particle flux and the impact of resuspension and lateral advection at the continental slope could be documented by combining microscopic analyses with pigment and alkenone determinations, which would not have been possible if only biogenic bulk element analyses had been carried out. At present, the relative contributions of particles with a different origin remain to be quantified, and it has also to be verified how to integrate the results from these recent processes in interpretations of palaeonto- 

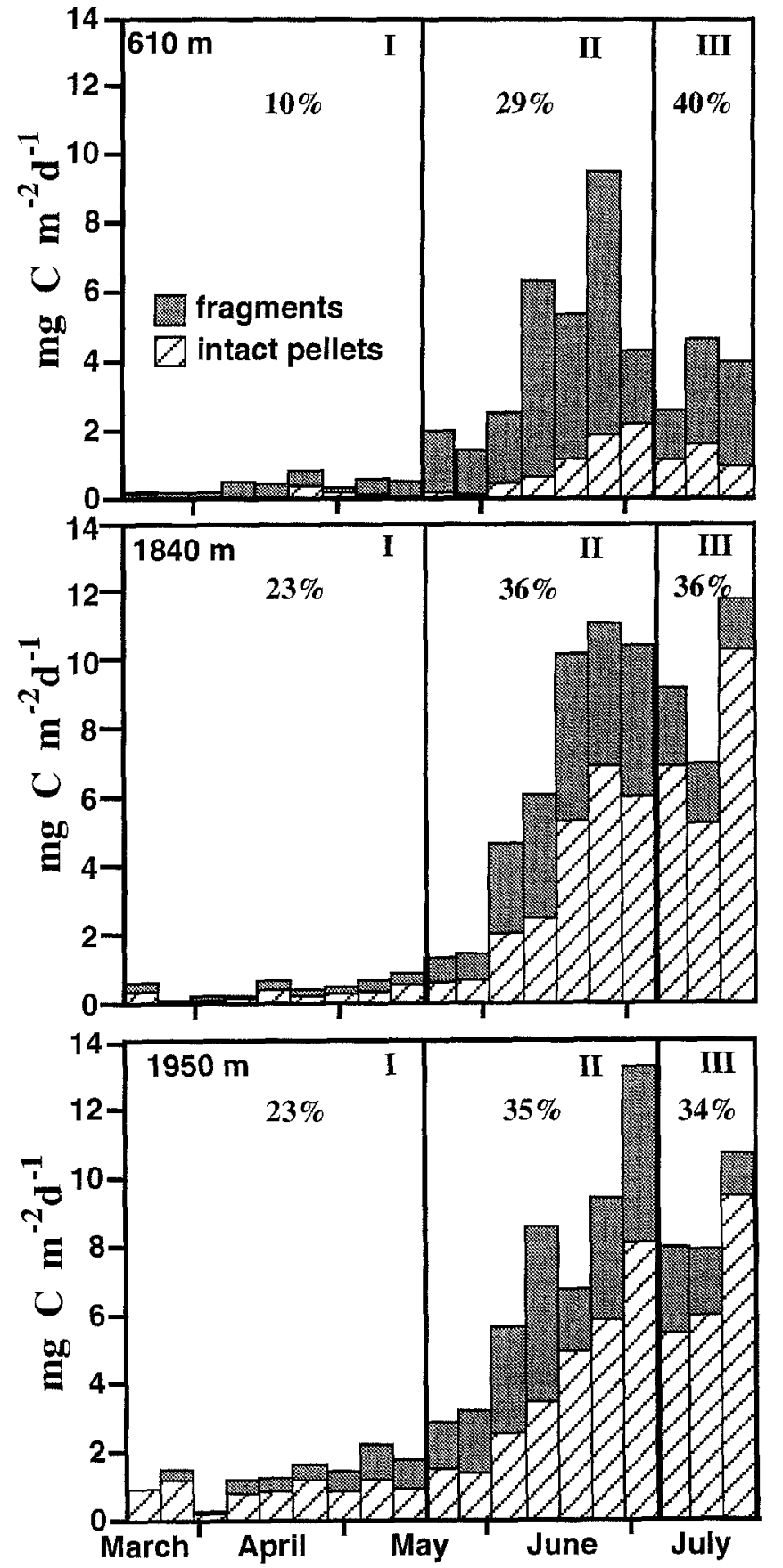

1991

Fig. 13 Vertical flux of faecal pellet carbon (FPC) between March and July 1991 at 610,1840 and $1950 \mathrm{~m}$ depth at the Barents Sea continental slope (water depth $2000 \mathrm{~m}$ ). Vertical lines separate phases I-III of particle flux. Averages for the percentage contribution of FPC (intact pellets and fragments) to total organic carbon flux are given for the three respective phases

logial records in the sediments. In particular, this holds true for ratios of saturated to unsaturated alkenones for reconstructing paleotemperatures (Prahl and Wakeham 1987), which remain to be verified for the Nordic seas.

\section{Norwegian-Greenland Sea: a comparative summary}

The overall objective of our studies is to link pelagic surface processes with particle exports to the deep Norwegian-Greenland Sea. Within the framework of the SFB 313, this aims at documenting the supply of food to the benthos and providing vital information for reconstructing the paleoenvironment from the sedimentary record.

A comparison of present hydrographic and production characteristics of both regions is given in Table 2 . The Norwegian Sea investigation site is characterized by a $500 \mathrm{~m}$ surface layer of Atlantic water, whereas in the Greenland Sea the upper $150 \mathrm{~m}$ are dominated by water of polar origin. As both sites are located at approximately the same latitude the seasonal solar irradiation is identical and the same holds true for nutrient reserves accumulating during winter, which are available for primary production in spring. Major differences, however, characterize both sites with respect to the hydrographic preconditions for primary production. A seasonal thermocline establishes in the Norwegian Sea, whereas in the Greenland Sea sea-ice melting, which is highly variable in time and space, controls early stratification.

Spring phytoplankton growth in the Norwegian Sea is under a strong zooplankton control. The ontogenetic vertical migration of herbivorous copepods (dominated by Calanus finmarchicus) ascending to surface layers from hibernation leads to a high grazing pressure on primary producers early in spring (Bathmann et al. 1990a). After the seasonal descent of these organisms to hibernation depths begins in summer, particle fluxes in the Nowegian Sea remain under biological control due to the seasonal delevopment of pteropods. New and regenerated production occur more or less in parallel thoughout the growth season (i.e. there is little seasonal variation in the $f$ ratio) and, therefore, they do not provide appropriate categories to explain the seasonal pattern of organic matter vertical flux.

Although the annual sedimentation maximum takes place in late summer/autumn, apparently relatively fresh material already reaches the sea floor in spring, which is readily incorporated by the benthos (Graf et al. 1994). The seasonal vertical flux maximum coincides with maximum pteropod fluxes, which is also the prominent event regarding planktonic organisms. Unfortunately, pteropods do not serve as indicators for pelagic processes in the geological record as their aragonite shells are rapidly dissolved.

The interannual variability of particle fluxes in the Norwegian Sea is probably governed by year to year differences in grazer development. Differences in the lateral advection of grazers such as the migrant populations of pteropods by the Norwegian Current may also contribute to variability (Wassmann et al. 1991). On longer time-scales, variabilities in the overall circulation regime of the Norwegian-Greenland Sea may be superimposed on interannual fluctuations. It is postu- 
Table 3 Annual vertical mass flux (DW=dry weight) and fluxes of carbonate $\left(\mathrm{CaCO}_{3}\right)$, particulate biogenic silica (PSi), particulate organic carbon (POC) and nitrogen (PON) between Septembers 1988 and 1991 in the Greenland Sea at $500 \mathrm{~m}, 1000 \mathrm{~m}$ and $2200 \mathrm{~m}$ depth. Due to an instrument failure no data are at hand for $2200 \mathrm{~m}$ depth for $1989 / 1990$

\begin{tabular}{lrlllll}
\hline Year & Depth $(\mathrm{m})$ & \multicolumn{5}{l}{ Annual flux $\left(\mathrm{g} \mathrm{m}^{-2}\right)$} \\
\cline { 3 - 7 } & & DW & $\mathrm{CaCO}_{3}$ & PSi & POC & PON \\
\hline $1988-1989$ & 500 & 22.79 & 8.56 & 2.39 & 3.81 & 0.50 \\
& 1000 & 10.50 & 3.30 & 1.20 & 1.30 & 0.20 \\
& 2200 & 12.96 & - & 0.43 & 0.33 & 0.04 \\
$1989-1990$ & 500 & 21.26 & 8.67 & 1.81 & 3.69 & 0.56 \\
& 1000 & 10.49 & 2.61 & 1.12 & 1.41 & 0.22 \\
& 2200 & - & - & - & - & - \\
$1990-1991$ & 500 & 12.31 & 2.30 & 0.59 & 1.07 & 0.13 \\
& 1000 & 10.19 & 1.57 & 0.51 & 0.75 & 0.10 \\
& 2200 & 9.44 & 2.77 & 0.42 & 0.36 & 0.04 \\
\hline
\end{tabular}

lated that the decline of the Icelandic herring population is related to such a long-term variability, which could have resulted in larger zooplankton stocks and may have increased grazer control on phytoplankton (Wassmann et al. 1991).

In the Greenland Sea, in contrast, vertical particle flux variability seems primarily hydrographically controled (ice-melting, vertical mixing and pack-ice drift; Koeve 1992). Despite the fundamental difference between the two regions in this respect, the total annual primary production, estimated from 20 measurements covering all seasons, is almost identical. The same holds true for new production as calculated from seasonal changes in the concentration and vertical distribution of nitrate (Table 3). The seasonal vertical flux pattern, however, largely differs relative to new production seasonality. In the Greenland Sea $97 \%$ of the annual new production takes place before mid-July, whereas $40 \%$ of the vertical particle exports from the euphotic zone are observed after this phase. For depths $>500 \mathrm{~m}$ this value even approaches $60 \%$. This indicates that organic matter degradation below the euphotic zone in the Greenland Sea strongly decreases after spring. In the Norwegian Sea the temporal pattern is more evenly distributed. A total of $60-70 \%$ of new production and 50 $60 \%$ of the annual particle exports from the euphotic zone are recorded until August. In contrast with the Greenland Sea, this also applies to particle fluxes measured at greater depths. The strong zooplankton control of particle fluxes in the Norwegian Sea apparently results in closer temporal coupling of new production and sedimentation, and organic matter degradation below the euphotic zone seems to be more continuous throughout the year compared with the Greenland Sea (Koeve 1992). Three-year averages of particle fluxes show that mass flux as well as carbonate and POC fluxes in the Norwegian Sea are higher than in the Greenland Sea, where in contrast, PSi and PON fluxes are higher (Tables 1 and 3). In the Greenland Sea a classic diatom spring sedimentation is indicated by a sharp increase in PSI flux in May/June, but diatoms were not the main contributors to the spring POC flux here.

Diatom composition is strongly modified during sinking and only minor portions reach the seafloor (Samtleben et al. 1994). Other prominent seasonal contributors to trap collection such as coccolithophorides, radiolarians and acantharians experience the same fate. Thus on a species level the pelagic signal becomes increasingly blurred with depth both by processes in the water column and by passing through the benthic 'filter'. Despite this reduction in the pelagic signals it is nevertheless possible to extract reliable general relations between pelagic assemblages and their remains in the sedimentary record provided that long-term multiyear data for vertical fluxes of organisms are available (Samtleben et al. 1994).

Our findings emphasize that pelagic systems with identical total and new production may largely differ with respect to the amounts and composition of exported particles and the seasonal vertical particle flux pattern. These differences would not be evident if only total primary production and POC export from the winter mixed layer were considered. Wefer (1989) summarizes POC fluxes from environments as different as the Nordic seas, Antarctic waters, the Sargasso Sea and different regions of the Pacific. Excluding annual POC fluxes from the Panama Basin $\left(4.3 \mathrm{~g} \mathrm{~m}^{-2}\right)$, the Bransfield Strait $\left(4.3 \mathrm{~g} \mathrm{~m}^{-2}\right)$ and the Weddell Sea $\left(0.03 \mathrm{~g} \mathrm{~m}^{-2}\right)$, the range of $0.40-2.9 \mathrm{~g} \mathrm{~m}^{-2}$ is very narrow and apparently cannot be related to primary production. More recent data from the Arabian Sea (Ittekott et al. 1992), the north-western Mediterranean (Miguel et al. 1994) and the equatorial upwelling off west Africa (Wefer and Fischer 1993) also fall in this range. The interannual variability of POC fluxes in the Norwegian and Greenland Seas covers this entire range. This strongly suggests that annual POC fluxes (and those of other bulk variables) measured at great depths are not a sensitive tool for distinguishing the specific production regimes characterizing different oceanic regions. A combination of bulk variable analysis with compounds that indicate the pelagic origin of particles and the process of their formation or modification (i.e. biomarkers) is certainly more powerful to relate pelagic processes to the sedimentary record.

Acknowledgements We acknowledge the contributions of all former members of the team, in particular Victor Smetacek, Uli Bathmann, Tom Noji and Bert Klein, who participated in the development of ideas and concepts and whose work contributed to the broad data base. We thank the masters and crews of research vessels Meteor, Polarstern, Poseidon and Valdivia for their professional help at sea throughout the years. H. Beese, T. Körner and E. Steen are thanked for their assistance at sea and with laboratory analyses. We appreciate valuable comments and suggestions by Drs. C. Turley and U. Bathmann as reviewers of the manuscript. The work was funded by Deutsche Forschungsgemeinschaft as part of the Sonderforschungsbereich 313 at Kiel University, Germany. This is publication No. 210 of the Sonderforschungsbereich 313 at Kiel University. 


\section{References}

Angel MV (1989) Does mesopelagic biology affect the vertical flux? In: Berger WM, Smetacek VS, Wefer G (eds) Productivity in the Ocean: Present and Past. Wiley, Chicester, pp 155173

Antia AN (1991) Microzooplankton in the pelagic food web of the East Greenland Sea and its role in sedimentation processes. Ber Sonderforschungsbereich 313 Univ Kiel 33:1-101

Antia AN, 15 others (1990) The pelagic system and vertical particle flux during autumn in the Greenland Sea, Jan Mayen Current. Ber Sonderforschungsbereich 313 Univ Kiel 26:154

Antia AN, Bauerfeind E, Bodungen B v, Zeller U (1993) Abundance, encystment and sedimentation of acantharia during autumn 1990 in the East Greenland Sea. J Plankton Res 15:99114

Arndt K (1990) Verbreitung, Produktion und Sedimentation von Diatomeen in der Grönlandsee. Diplomarbeit, Univ Kiel:184

Bathmann UV (1988) Mass occurence of Salpa fusiformis in the spring of 1984 of Ireland: implications for sedimentation processes. Mar Biol 97:127-135

Bathman UV, Noji TT, Voss M, Peinert R (1987) Copepod fecal pellets: abundance, sedimentation and content at a permanent station in the Norwegian Sea in May/June 1986. Mar Ecol Prog Ser 38:45-51

Bathmann UV, Noji TT, Bodungen B v (1990a) Copepod grazing in later winter in the Norwegian Sea - a factor in the control of spring phytoplankton growth? Mar Ecol Prog Ser 60:225233

Bathmann UV, Peinert R, Noji TT, Bodungen B v (1990b) Pelagic origin and fate of sedimenting particles in the Norwegian Sea. Prog Oceanogr 24:117-125

Bathmann UV, Noji TT, Bodungen B v (1991) Sedimentation of pteropods in the Norwegian Sea in autumn. Deep-Sea Res 38:1341-1360

Bauerfeind E, Bodungen B v, Arndt K, Koeve W. Particle flux and composition of sedimenting matter in the Greenland Sea. $\mathrm{J}$ Mar Syst, in press

Betzer PR, Shawers WJ, Laws EA, Winn CD, Di Tullio GR, Kroopwick PM (1984) Primary productivity and particle fluxes on a transect of the equator at $153^{\circ} \mathrm{W}$ in the Pacific Ocean. Deep-Sea Res 31:1-11

Berger WM, Wefer G (1990) Export production: seasonality and intermittency, and paleooceanographic implications. Palaeogeogr Palaeoclimatol Palaeoecol 89:245-254

Billet DSM, Lampitt RS, Rice AL, Mantoura RFC (1983) Seasonal sedimentation of phytoplankton to the deep-sea benthos. Nature 302:520-522

Blaume F (1992) Hochakkumulationsgebiet an norwegischen Kontinentalhang: Sedimentologische Abbilder topographicgeführter Strömungsmuster. Ber Sonderforschungsbereich 313 Univ Kiel 36:1-150

Blindheim J (1989) Cascading of Barents Sea bottom water into the Norwegian Sea. Rapp P-v Réun Cons Int Mer 188:49-58

Bodungen B $\vee$ (1986) Phytoplankton growth and krill grazing during spring in the Bransfield Strait, Antarctica. Implications from sediment trap collections. Polar Biol 6:153-160

Bodungen B v (1989) Pelagische Primärproduktion und vertikaler Partikelfluß im Ozean. Habilitationsschrift Univ Kiel:1-158

Bodungen B v, Bröckel K, Smetacek V, Zeitzschel B (1981) Growth and sedimentation of the phytoplankton spring bloom in the Bornholm Sea (Baltic Sea). Kieler Meeresforsch Sonderband 5:49-60

Bodungen B v, Fischer G, Nöthig E-M, Wefer G (1987) Sedimentation of krill faeces during spring development of phytoplankton in the Bransfield Strait, Antarctica. In: Degens ET, Izdar E, Honjo S (eds) Mitt Geol-Paläont Inst Univ Hamburg, SLOPE/UNEP Sonderband 62:243-257
Bodungen B v, Bauerfeind E, Koeve W, Zeitzschel B (1990) Plankton development and vertical particle flux in June/July 1989 in the south western Greenland Sea. Eos 70:213

Bodungen B v, Bathmann U, Voss M, Wunsch M (1991a) Vertical particle flux in the Norwegian Sea - Resuspension and interannual variability. In: Wassmann $P$, Heiskanen AS, Lindah] O (eds) Sediment Trap Studies in the Nordic Countries 2. Nurmi Print Oy, Nurmijärvi, pp 116-136

Bodungen B v, Wunsch M, Füderer H (1991b) Sampling and analysis of suspended and sinking particles in the northern North Atlantic. In: Hurd DC, Spencer DW (eds) Marine Particles: Analysis and Characterization. Am Geophys Union, Geophys Monogr 63:47-56

Buessler KO (1991) Do upper-ocean sediment traps provide an accurate record of particle flux? Nature 353:420-423

Deuser WG (1987) Variability of hydrography and particle flux: transient and long-term relationships. In: Degens ET, Izdar E, Honjo S (eds) Mitt Geol-Paläont Inst Univ Hamburg, SLOPE/UNEP Sonderband 62:179-193

Eppley RW (1989) New production: history, methods, problems. In: Berger WM, Smetacek VS, Wefer G (eds) Productivity in the Ocean: Present and Past. Wiley, Chichester. pp 85-97

Eppley RW, Koeve W (1990) Nitrate use by plankton in the eastern subtropical North Atlantic, March-April 1989. Limnol Oceanogr 35:1781-1788

Fasham MJR, Sarmiento JL, Slater RD, Ducklow HW, Williams $R$ (1993) Ecosystem behaviour at Bermuda Station " $S$ " and Ocean Weather Ship "India": a general circulation model and observational analysis. Global Biogeochem Cyles, 7:379-415

Fowler SW, Knauer GA (1986) Role of large particles in the transport of elements and organic compounds through the ocean water column. Prog Oceanogr 16:147-194

Fürderer H (1991) Zooplankton in Sinkstoffallen in Beziehung zur vertikalen Verteilung im Europäischen Nordmeer. Diplomarbeit Univ Kiel:1-73

Gardner WD (1989) Baltimore Canyon as a modern conduit of sediment to the deep sea. Deep-Sea Res 36:323-358

Garside C, Garside JC (1993) The "f-ratio" on $20^{\circ} \mathrm{W}$ during the North Atlantic Bloom Experiment. Deep-Sea Res 40:75-90

Gloe T (1988) Reaktionen natürlicher Phytoplanktonpopulationen auf Licht- und Nährsalzänderungen in Tankexperimenten. Diplomarbeit Univ Kiel:1-95

Gonzales H, Smetacek V (1994) The possible role of the cyclopoid copepod Oithona in retarding vertical flux of zooplankton material. Mar Ecol Prog Ser 113:233-246

Gradinger R, Baumann MEM (1991) Distribution of phytoplankton communities in relation to the large scale hydrographical regime in the Fram Strait. Mar Biol 111:311-321

Graf G, Gerlach SA, Linke P, Queisser W, Ritzrau W, Scheltz A, Thomsen L, Witte U (1994) Benthic-pelagic coupling in the Norwegian-Greenland Sea and its effect on the geological record. Geol Rundsch 84:49-58

Hargrave BT, v Bodungen B, Stoffyn-Egli P, Mudie PJ (1994) Seasonal variability in particle sedimentation under permanent ice cover in the Arctic Ocean. Cont Shelf Res 14:279293

Hassan M (1991) Die Exsudation des Phytoplanktons in der westlichen Grönlandsee. Diplomarbeit Univ Kiel:1-112

Honjo S (1990) Particle fluxes and modern sedimentation in polar oceans. In: Smith WO Jr (ed) Polar Oceanography Part B. Chemistry, Biology, Geology. Academic Press, London, pp $687-737$

Humborg C (1991) Experimentelle Untersuchungen zum Umsatz von Phosphor und Stickstoff in natürlichen Planktongemeinschaften. Diplomarbeit Univ Kiel:1-107

Ittekott V, Haake B, Bartsch M, Nair RR, Ramaswamy V (1992) Organic carbon removal in the sea: the continental connection. In: Summerhayes CP, Prell WL, Emais K (eds) Upwelling Systems: Evolution Since the Early Miocene. Spec Publ Geol Soc London No 64:167-176 
Kirchman DL, Suzuki Y, Garside C, Ducklow HW (1991) High turnover rates of dissolved organic carbon during a spring phytoplankton bloom. Nature 352:612-614

Knauer G, Asper V (eds) (1989) Sediment trap technology and sampling. US GOFS Planning Report 10, Woods Hole Oceanographic Institution:1-94

Koeve W (1992) New production of phytoplankton in the tropical and subarctic North Atlantic. Dissertation Univ Kiel:1-98

Koeve W, Eppley RW, Podewski S, Zeitzschel B (1993) An unexpected nitrate distribution in the tropical North Atlantic at $18^{\circ} \mathrm{N}, 30^{\circ} \mathrm{W}-$ implications for new production. Deep-Sea Res 40:521-536

Lampitt RS, Noji TT, Bodungen B v (1990) What happens to zooplankton faecal pellets? Implications for material flux. Mar Biol 104:15-23

Lampitt RS, Hillier WR, Challenor PG (1993) Seasonal and diel variation in the open ocean concentration of marine snow aggregates. Nature 362:737-739

Lee C, Wakeham SG, Hedges JI (1988) The measurement of oceanic particle flux - are swimmers a problem? Oceanography $1: 34-36$

Lee C, Hedges JI, Wakeham SG, Zhu N (1992) Effectiveness of various treatments in retarding microbial activity in sediment trap material and their effect on the collection of swimmers. Limnol Oceanogr 37:117-130

Legendre L, Gosselin M (1989) New production and export of organic matter to the deep ocean: consequences of some recent discoveries. Limnol Oceanogr 34:1374-1380

Legendre L, Le Fevre (1989) Hydrodynamical singularities as controls of recycled versus export production in oceans. In: Berger WM, Smetacek VS, Wefer G (eds) Productivity in the Ocean: Present and Past. Wiley, Chichester, pp 49-63

Longhurst AR, Harrison WG (1988) Vertical nitrogen flux from the euphotic zone by diel migrant zooplankton and necton. Deep-Sea Res 35:881-889

Machado E (1993) Production, sedimentation and dissolution of biogenic silica in the northern North Atlantic. Dissertation Univ Kiel:1-123

Miquel JC, Fowler SW, La Rosa J, Buat-Menard P (1994) Dynamics of the downward flux of particles and carbon in the open northwestern Mediterranean Sea. Deep-Sea Res 41 (2) :243-261

Noji TT (1991) The influence of macrozooplankton on vertical particle flux. Sarsia 76:1-9

Noji TT, Estep KW, Macintyre F, Norrbin F (1991) Image analysis of feacal material grazed upon by three species of copepods: evidence for coprorhexy, coprophagy and coprochaly. $\mathrm{J}$ Mar Biol Assoc UK 71:465-480

Peeken I. Modifikation von Markerpigmenten im pelagischen Nahrungsnetz des Europäischen Nordmeeres und ihre Abbildung im vertikalen Partikelfluß. Dissertation Univ Kiel, in preparation

Peinert R, Bathmann UV, Bodungen B v, Noji TT (1987) The impact of grazing on spring growth and sedimentation in the Norwegian Current. In: Degens ET, Izdar E, Honjo S (eds) Mitt Geol-Paläont Inst Univ Hamburg. SCOPE/UNEP Sonderband 62:149-164

Peinert R, Bodungen B v, Smetacek VS (1989) Food web structure and loss rate. In: Berger WM, Smetacek VS, Wefer G (eds) Productivity in the Ocean: Present and Past. Wiley, Chichester, pp 35-48

Prahl FG, Wakeham SG (1987) Calibration of unsaturation patterns in long chain ketone compositions for palaeotemperature assessments. Nature 330:367-369

Puch M (1990) Zum Silikathaushalt des Pelagials im Europäischen Nordmeer. Diplomarbeit Univ Kiel:1-75

Riebesell U, Wolf-Gladrow DA (1992) The relationship between physical aggregation of phytoplankton and partical flux: a numerical model. Deep-Sea Res 39:1085-1102
Samtleben C, Schäfer P, Andruleit H, Baumann A, Baumann KH, Kohly A, Mathiessen J, Schröder-Ritzrau A (1994) Plankton in the northern North Atlantic: from living communities to sediment assemblages - an actualistic approach. Geol Rundsch 84:108-136

Siegel DA, Granata TC, Michaels AF, Dickey TD (1990) Mesoscale eddy diffusion, particle sinking, and the interpretation of sediment trap data. J Geophys Res 95 (C4):5305-5311

Smetacek VS (1984) The supply of food to the benthos. In: MJR Fasham (ed) Flow of Energy and Materials in Marine Ecosystems. Plenum Press, New York London, pp 517-548

Smetacek VS, Scharek R, Nöthig E-M (1990) Seasonal and regional variation in the pelagial and its relationship to the life history of krill. In: Kerry KR, Hempel G (eds) Antarctic Ecosystems. Ecological Change and Conservation. Springer, Berlin, pp 103-114

Smith DC, Simon M, Alldredge AL, Azam F (1992) Intense hydrolytic enzyme activity on marine aggregates and implications for rapid particle solution. Nature 359:139-142

Smith WO (1987) Phytoplankton dynamics in the marginal ice zones. Oceanogr Mar Biol Annu Rev 25:11-38

Smith WO, Codispoti LA, Nelson DM, Manley T, Buskey EJ, Niebauer HJ, Cota GF (1991) Importance of phaeocystis blooms in the high-latitude ocean carbon cycle. Nature $352: 514-516$

Thomsen C (1993) Verfolgung pelagischer Prozesse mit Hilfe von biochemischen Komponenten am Beispiel der Alkenone $\left(\mathrm{C}_{37: 3}, \mathrm{C}_{37: 2}\right)$. Dissertation Univ Kiel:1-130

Voss M (1991a) Content of copepod feacal pellets in relation to food supply in Kiel Bight and its effect on sedimentation rate. Mar Ecol Prog Ser 75:217-222

Voss M (1991b) Räumliche und zeitliche Verteilung stabiler Isotope $\left(\delta^{15} \mathrm{~N},{ }^{13} \mathrm{C}\right)$ in suspendierten Partikeln im Nördlichen Nordatlantik. Ber Sonderforschungsbereich 313 Univ Kiel 32:1-112

Walsh I, Fisher K Murray D, Dymond J (1988) Evidence for resuspension of rebound particles from near bottom sedimenttraps. Deep-Sea Res 35:59-70

Walsh JJ (1983) Death in the sea: enigmatic phytoplankton losses. Prog Oceanogr 12:1-86

Walsh JJ (1989) How much shelf production reaches the deep ocean? In: Berger WM, Smetacek VS, Wefer G (eds) Productivity in the Ocean: Present and Past. Wiley, Chichester, pp 175-191

Wassmann P, Vernet M, Mitchell BG, Rey F (1990) Mass sedimentation of Phaeocystis pouchetii in the Barents Sea. Mar Ecol Prog Ser 66:183-195

Wassmann P, Peinert R, Smetacek VS (1991) Patterns of production and sedimentation in the boreal and polar Northeast Atlantic. Polar Res 10:209-228

Wefer G (1989) Particle flux in the ocean: effects of episodic production. In: Berger WM, Smetacek VS, Wefer G (eds) Productivity in the Ocean: Present and Past. Wiley, Chichester, pp 139-154

Wefer G, Fischer G (1993) Seasonal patterns of vertical particle flux in equatorial and coastal upwelling areas of the eastern Atlantic. Deep-Sea Res 40:1613-1645

Wefer G, Fischer G, Fütterer DK, Gersonde R (1988) Seasonal particle flux in the Bransfield Strait, Antarctica. Deep-Sea Res 35:891-898

Wille M (1988) Experimente zum Abbau von Kopepoden-Kotballen. Diplomarbeit Univ Kiel:1-58

Zeller U (1990) Untersuchungen zum Vorkommen und zur Nahrungsökologie von Copepoden in der Grönlandsee. Diplomarbeit Univ Kiel:1-73

Zeller U. Vorkommen und Sekundärproduktion des herbivoren Zooplanktons im Europäischen Nordmeer. Dissertation Univ Kiel, in preparation 